Article

\title{
Comparative Evaluation of Adsorption of Major Enzymes in a Cellulase Cocktail Obtained from Trichoderma reesei onto Different Types of Lignin
}

\author{
Dae-Seok Lee ${ }^{1}$, Younho Song ${ }^{1}$, Yoon-Gyo Lee ${ }^{2}$ and Hyeun-Jong Bae ${ }^{1,3, *}$ \\ 1 Bio-Energy Research Center, Chonnam National University, Gwangju 500-575, Korea; \\ realstone@hanmail.net (D.-S.L.); jagnad@naver.com (Y.S.) \\ 2 Department of Wood Science and Landscape Architecture, Chonnam National University, \\ Gwangju 500-757, Korea; spake123@naver.com \\ 3 Department of Bioenergy Science and Technology, College of Agriculture and Life Sciences, \\ Chonnam National University, Gwangju 500-757, Korea \\ * Correspondence: baehj@chonnam.ac.kr; Tel.: +81-62-530-2097
}

check for updates

Citation: Lee, D.-S.; Song, Y.; Lee,

Y.-G.; Bae, H.-J. Comparative

Evaluation of Adsorption of Major

Enzymes in a Cellulase Cocktail

Obtained from Trichoderma reesei onto

Different Types of Lignin. Polymers

2022, 14, 167. https://doi.org/

$10.3390 /$ polym 14010167

Academic Editor: Daniel

Gonçalves Gomes

Received: 30 November 2021

Accepted: 29 December 2021

Published: 1 January 2022

Publisher's Note: MDPI stays neutral with regard to jurisdictional claims in published maps and institutional affiliations.

Copyright: (C) 2022 by the authors. Licensee MDPI, Basel, Switzerland. This article is an open access article distributed under the terms and conditions of the Creative Commons Attribution (CC BY) license (https:// creativecommons.org/licenses/by/ $4.0 /)$.
Abstract: Cellulase adsorption onto lignin decreases the productivity of enzymatic hydrolysis of lignocellulosic biomass. Here, adsorption of enzymes onto different types of lignin was investigated, and the five major enzymes-cellobiohydrolases (CBHs), endoglucanase (Cel7B), $\beta$-glucosidase (Cel3A), xylanase (XYNIV), and mannanase (Man5A) - in a cellulase cocktail obtained from Trichoderma reesei were individually analyzed through SDS-PAGE and zymogram assay. Lignin was isolated from woody (oak and pine lignin) and herbaceous (rice straw and kenaf lignin) plants. The relative adsorption of $\mathrm{CBH}$ s compared to the control was in the range of $14.15-18.61 \%$. The carbohydrate binding motif (CBM) of the CBHs contributed to higher adsorption levels in oak and kenaf lignin, compared to those in pine and rice lignin. The adsorption of endoglucanase (Cel7B) by herbaceous plant lignin was two times higher than that of woody lignin, whereas XYNIV showed the opposite pattern. $\beta$-glucosidase (Cel3A) displayed the highest and lowest adsorption ratios on rice straw and kenaf lignin, respectively. Mannanase (Man5A) was found to have the lowest adsorption ratio on pine lignin. Our results showed that the hydrophobic properties of CBM and the enzyme structures are key factors in adsorption onto lignin, whereas the properties of specific lignin types indirectly affect adsorption.

Keywords: lignin adsorption; cellobiohydrolases (CBHs); endoglucanase; $\beta$-glucosidase; xylanase; mannanase

\section{Introduction}

Lignocellulosic biomass is considered an alternative to petroleum as an energy resource and is used to obtain bioconversion products for subsequent biochemical and/or energy production [1]. However, the structural complexity of lignocellulose and its recalcitrance to degradation by hydrolytic enzymes reduces saccharification efficiency, and increase the costs to improve bioconversion rate, which, in turn, reduces the price competitiveness of the bioconversion products.

The presence of lignin hinders enzymatic hydrolysis of lignocellulose. Two major factors contribute to the negative impact of lignin on hydrolysis. The first factor is the structural recalcitrance of lignocellulose due to lignin. Lignocellulose is composed of three major polymers: lignin, hemicellulose, and cellulose. Lignin is a highly oxygenated aromatic polymer and binds cellulose microfibrils comprised of $\beta-1,4$-D-glucose polysaccharide chain bundles, ranging from 10 to $35 \mathrm{~nm}$ in diameter, together with a hemicellulose linker. Cellulose is tightly packed with inter- and intra- hydrogen bonds between individual cellulose chains. The difference in hydrogen-bonding networks between each cellulose chain within the microfibril unit results in three different recalcitrance behaviors [2,3]. 
During pretreatment of lignocellulosic biomass, lignin acts as a physical and chemical barrier to restrict cellulose swelling or structural modification of cellulose. Lee et al. (2020) showed that the lignin barrier affects cellulose modification under different pretreatment conditions, and three types of cellulose are released based on the enzymatic hydrolysis rate [4]. This is due to differences in lignin composition and compatibility between the pretreatment method and the lignocellulose feedstock type. The second factor is an enzymerelated retardation of hydrolysis. Cellulolytic and xylanolytic enzymes have been reported to be adsorbed onto lignin, and thereby accessibility of these hydrolytic enzymes is restricted. In particular, cellobiohydrolases (CBHs) with a tunnel-shaped catalytic site and hydrophobic carbohydrate binding motif (CBM) interact preferentially with hydrophobic surfaces of solid cellulose fibers to release soluble cellobiose through the progressive action [5-7]. Lignin also associates preferentially with the hydrophobic surfaces of cellulose and cellulase (steric hindrance), and was previously reported to block enzyme-cellulose productive adsorption [8,9]. Thus, significant inhibition of enzymatic hydrolysis occurs in lignin-containing pretreated lignocellulose.

Pretreatment of the lignocellulosic biomass is required to remove or reduce inhibition by lignin, and to modify cellulose structure to enhance enzymatic hydrolysis. Kumar et al. (2009) performed a characterization of cellulase adsorption capacities of lignin and cellulose in biomass pretreated with different methods such as ammonia fiber expansion (AFEX), ammonia recycle percolation (ARP), dilute sulfuric acid (DA), flowthrough (FT), lime, and steam explosion with $\mathrm{SO}_{2}$ [10]. The isotherm parameters of enzyme adsorption have been summarized based on diverse types of lignin isolated from different pretreated-lignocellulose samples. The lignin isolated from pine, poplar and corn stove pretreated by organosolv or steam explosion showed a much higher maximum adsorption capacity than that pretreated by alkali, dilute acid, ammonia, and sulfonated alkali [11]. Lignin in organosolv pretreated pine was characterized with high hydrophobicity, and a $23-30 \%$ reduction in hydrophobicity of the lignin by carboxylation and sulfonation led to a 76-96\% reduction in lignin inhibition [12]. These results clearly indicate that non-productive lignin adsorption on the cellulase negatively affects the enzymatic hydrolysis rate.

Enzyme adsorption onto lignin has been reported with chemically modified [12-17] and native lignin [18]. However, quantification of the enzyme adsorption has been performed with a single type of enzyme, which was purified from the cellulase cocktail or produced via recombinant expression. In these cases, a single type of enzyme is clearly overadsorbed, compared to the case when a cellulase cocktail is used. Therefore, quantification of adsorption of specific types of enzymes onto native lignin in a cellulase cocktail is also necessary. Such a quantification study will provide a standard for the adsorption capacity of specific enzyme types that can be altered depending on different types of lignin. To this end, lignin isolated from the lignocelluloses pretreated with popping methods where no chemicals are used $[19,20]$ may be an appropriate material to serve as the standard for quantification of adsorption capacity. Here, we isolated lignin from various lignocellulosic biomass types pretreated with popping methods, including hardwood (Quercus acutissima), softwood (Pinus densiflora), and agricultural herbaceous plants (rice straw and kenaf), and analyzed the adsorption ratio of the major enzymes that function as gate keepers for the cleavage of $\beta-1,4$ glycosidic linkages in a cellulase cocktail from Trichoderma reesei. Other enzymes, such as $\beta$-glucosidase from Aspergillus niger and xylanase from Thermomyces lanuginosus, were also quantified as supplementary enzymes with the native lignin.

\section{Materials and Methods}

\subsection{Enzyme Preparation}

The cellulase cocktail (Trichoderma reesei, celluclast $1.5 \mathrm{~L}$ ) were purchased from Novozymes (Bagsværd, Denmark). $\beta$-glucosidase (Aspergillus niger) were purchased from Megazyme (Lot 141001, Wicklow, Ireland). The xylanases from Thermomyces lanuginosus were purchased from Sigma-Aldrich (X2753-50G, St. Louis, MI, USA). 


\subsection{Lignin Isolation}

Hardwood (oak, Quercus acutissima), softwood (pine, Pinus densiflora), and agricultural herbaceous plants (rice straw and kenaf) were chopped into lengths of approximately $2 \mathrm{~cm}$, and soaked in tap water for 1 day before placement in a laboratory-scale cast iron cylindrical reactor (3 L) to conduct the popping pretreatment [19]. The reactor was heated at a rate of between 15 and $20{ }^{\circ} \mathrm{C}$ per minute until $220^{\circ} \mathrm{C}$ and $298.69 \mathrm{~Pa}\left(21 \mathrm{~kg} \mathrm{f} \mathrm{cm}^{-2}\right)$. The hatch was rapidly opened to expose the sample to atmospheric pressure. The popped samples were dried and ground to 251-422 $\mu \mathrm{m}$ particle size with a Willy mill fitted equipped with stainless steel blades. Lignin isolation from the samples was conducted with a fresh cellulase cocktail in all reactions that repeated until the carbohydrates were nearly removed. The isolated lignin were filtered through a 100 mesh screen cup (Cot. S3895, Sigma-Aldrich, St. Louis, MI, USA), freeze dried, and stored at room temperature.

\subsection{Lignin Adsorption}

Enzyme adsorption onto lignin was performed in $1 \mathrm{~mL}$ of $20 \mathrm{mM}$ citrate buffer (pH 5.0) with $0.5,1.0,2.5,5.0,10.0,15.0$, and $20.0 \mathrm{mg} \mathrm{mL}^{-1}$ lignin (oak, pine, rice straw, and kenaf) and $15 \mathrm{FPU}$ cellulase cocktail $\mathrm{mL}^{-1}\left(126 \mu \mathrm{g} \cdot \mathrm{mL}^{-1}\right)$ at $50^{\circ} \mathrm{C}$ for $1 \mathrm{~h}$. The tubes were centrifuged to separate supernatant and pellet at 35,000 RCF (relative centrifugal force; CT15RE, Hitachi Koki Co., Ltd., Tokyo, Japan) for $10 \mathrm{~min}$. The supernatants were diluted 5-10 times with $20 \mathrm{mM}$ citrate buffer ( $\mathrm{pH}$ 5.0) for consistent and accurate protein quantification. The free protein in each supernatant was measured with Bio-Rad protein assay solution (Cat. No. 500-0006, BIO-RAD, Hercules, CA, USA) and ELISA (MULTISCAN EX, Thermo Scientific, Waltham, MI, USA) at $595 \mathrm{~nm}$. The protein concentration adsorbed onto the lignin was quantified using the following equation:

$$
[E]_{\mathrm{ad}}=[\mathrm{E}]_{\text {total }}-[\mathrm{E}]_{\text {free }}
$$

where $[E]_{a d}$ is the protein concentration adsorbed onto the lignin. $[E]_{\text {total }}$ is the initial enzyme amount before the adsorption. $[\mathrm{E}]_{\text {free }}$ is the protein concentration in the supernatant after lignin adsorption. The protein standard curve was derived with bovine serum albumin (BSA) and used to calculate the protein concentration in all experiments.

\subsection{Adsorption of Cellobiohydrolases (CBHs) onto Lignin}

The pellet obtained after centrifugation in the previous section was washed two times with $20 \mathrm{mM}$ citrate buffer. After centrifugation at 35,000 RCF for $10 \mathrm{~min}$, the pellet was incubated with dissociation buffer ( $100 \mu \mathrm{L} 10 \%$ SDS, $100 \mu \mathrm{L}$ sample buffer, and adjusting the final volume to $300 \mu \mathrm{L}$ with distilled water) to dissociate the enzymes from the lignin. The contents of the tubes were brought to the boil, maintained for $10 \mathrm{~min}$, and then centrifuged at 35,000 RCF for $10 \mathrm{~min}$. The dissociated proteins were then subjected to SDS-PAGE. The control sample was prepared with $20 \mu \mathrm{L}$ for $15 \mathrm{FPU} \mathrm{mL}^{-1}$ cellulase cocktail and brought to its final volume of $300 \mu \mathrm{L}$ with the dissociation buffer. The loading volumes were $2.5,5$, 10 , and $15 \mu \mathrm{L}$ for the control, and 5, 10, 20, 30, and $40 \mu \mathrm{L}$ for the dissociation samples from the lignin to produce more bands having measurable and distinguishable intensities. The proteins separated on the electrophoresis gel were stained with Coomassie brilliant blue R-250. Adsorption rate was calculated by measuring the intensities of the bands on the gel with histogram quantification software (Adobe photoshop CS6, Adobe Inc., San Jose, CA, USA) following the method outlined at https://support.dalton.missouri.edu/index.php/ wiki/Public:Quantifying_Color_Intensity (accessed on 1 December 2021) [21].

\subsection{Adsorption of Endoglucanases (EGs) onto Lignin}

Adsorption of endo-glucanases (EGs) onto lignin was conducted with $20 \mu \mathrm{L}$ of the 15 FPU cellulase cocktail $\left(126 \mu \mathrm{g} \cdot \mathrm{mL}^{-1}\right)$ and $10 \mathrm{mg} \mathrm{mL}^{-1}$ lignin (oak, pine, rice straw, and kenaf) in $20 \mathrm{mM}$ citrate buffer with a final volume of $1 \mathrm{~mL}$, which was incubated at $50^{\circ} \mathrm{C}$ for $1 \mathrm{~h}$. The mixture was then centrifuged at 35,000 RCF for $10 \mathrm{~min}$ to obtain the supernatant 
and pellet fractions. The supernatant and pellet fractions were used to measure the total activity of the EGs and the specific individual enzyme (Cel7B) for the adsorption capacity of the lignin. The control was prepared with a $20 \mu \mathrm{L}$ cellulase cocktail (15 FPU mL ${ }^{-1}$ ) and brought to its final volume of $1 \mathrm{~mL}$ final volume with $20 \mathrm{mM}$ citrate buffer ( $\mathrm{pH}$ 5.0). The supernatant $(100 \mu \mathrm{L})$ including free enzymes was used to measure the EGs activity in $500 \mu \mathrm{L}$ total volume of $20 \mathrm{mM}$ citrate buffer $(\mathrm{pH} 5.0)$ with $100 \mu \mathrm{L} 1 \% \mathrm{CMC}$ at $50{ }^{\circ} \mathrm{C}$ for $30 \mathrm{~min}$.

Zymogram analysis was conducted with a pellet fraction obtained as described above to measure the activity of the endoglucanase Cel7B in the cellulase cocktail. The pellet fractions obtained from oak, pine, rice straw, and kenaf lignin were incubated with $300 \mu \mathrm{L}$ dissociation buffer at room temperature, and boiled for $10 \mathrm{~min}$. After centrifugation at 35,000 RCF for $10 \mathrm{~min}$, the solution including dissociated enzymes was loaded on SDSPAGE including $30 \mu \mathrm{L} \mathrm{mL}^{-1} 1 \% \mathrm{CMC}$. The loading volumes were 1,2 , and $4 \mu \mathrm{L}$ for the control (10× dilution), and 2, 4, and $8 \mu \mathrm{L}$ for the dissociated EGs. After electrophoresis, the gel was added into $50 \mathrm{~mL}$ refolding buffer containing $50 \mathrm{~mL} 20 \mathrm{mM}$ citrate buffer (pH 5.0),

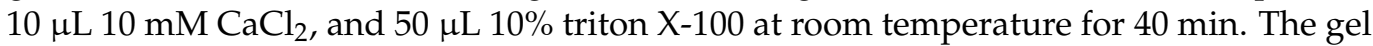
was incubated in $50 \mathrm{~mL}$ fresh solution of $20 \mathrm{mM}$ citrate buffer $\left(\mathrm{pH} \mathrm{5.0)}\right.$ ) at $40{ }^{\circ} \mathrm{C}$ for $1 \mathrm{~h}$ and washed with $20 \mathrm{mM}$ phosphate buffer ( $\mathrm{pH} 7.0$ ). Then, the gel was stained with $0.1 \%$ Congo red solution for $30 \mathrm{~min}$, and destained with $1 \mathrm{M} \mathrm{NaCl}$ until bands of hydrolysis zones appeared. For better visual clarity, $0.5 \%$ acetic acid was added to the gel to change the background color from red to dark blue. The bands' intensities were quantified using the same method described above.

\subsection{Lignin Adsorption on the $\beta$-Glucosidases from Different Fungi}

$\beta$-glucosidase adsorption onto lignin was performed in $20 \mathrm{mM}$ citrate buffer ( $\mathrm{pH}$ 5.0) with a $1 \mathrm{~mL}$ final volume and $20 \mu \mathrm{L}$ cellulase cocktail $\left(15 \mathrm{FPU} \mathrm{mL}{ }^{-1}\right.$ ) with $10 \mathrm{mg} \mathrm{mL}^{-1}$ lignin at $50{ }^{\circ} \mathrm{C}$ for $1 \mathrm{~h}$. The mixture was then centrifuged to obtain supernatant and pellet fractions. A total of $100 \mu \mathrm{L}$ of the supernatant and control solution (described above) were separately incubated in $1 \mathrm{~mL}$ of $20 \mathrm{mM}$ citrate buffer ( $\mathrm{pH}$ 5.0) containing $20 \mu \mathrm{L}$ of $50 \mathrm{mg} \mathrm{mL}^{-1} p \mathrm{NPG}^{-1}$ (4-Nitrophenyl $\beta$-D-glucopyranoside) at $50{ }^{\circ} \mathrm{C}$ for $10 \mathrm{~min}$ or with $2 \mathrm{mg} \mathrm{mL}^{-1}$ cellobiose at $50{ }^{\circ} \mathrm{C}$ for $30 \mathrm{~min}$. The $p \mathrm{NP}$ standard curve was used to measure the $\beta$-glucosidase activity. The products from cellobiose were analyzed by HPLC.

Adsorption of $\beta$-glucosidase from $A$. niger onto lignin was conducted in $1 \mathrm{~mL}$ of $20 \mathrm{mM}$ citrate buffer ( $\mathrm{pH}$ 5.0) containing $25 \mu \mathrm{g} \beta$-glucosidase from $A$. niger, and $10 \mathrm{mg} \mathrm{mL}^{-1}$ lignin or without lignin as the control. The tubes were incubated at $50{ }^{\circ} \mathrm{C}$ for $1 \mathrm{~h}$. The pellet fractions were separated, and the enzymes were dissociated with $200 \mu \mathrm{L}$ of final volume of dissociation buffer. The solution including dissociated enzymes and the control were subjected to SDS-PAGE. Sample volumes were 10, 20, and $30 \mu \mathrm{L}$, whereas volumes of control were 10,15 , and $20 \mu \mathrm{L}$.

\subsection{Lignin Adsorption on the Xylanases under Different Enzyme Conditions}

Adsorption of xylanases from $T$. reesei and T. lanuginosus was assessed in $1 \mathrm{~mL}$ of $20 \mathrm{mM}$ citrate buffer ( $\mathrm{pH} 5.0$ ) containing $10 \mathrm{mg} \mathrm{mL}^{-1}$ lignin and $20 \mu \mathrm{L}$ of the cellulase cocktail for $15 \mathrm{FPU} \mathrm{mL} \mathrm{mL}^{-1}$ or $25 \mu \mathrm{L}$ of $0.1 \mathrm{~g} \mathrm{~mL}^{-1}$ xylanase of $T$. lanuginosus at $50{ }^{\circ} \mathrm{C}$ for $1 \mathrm{~h}$. The supernatant and pellet were separated by centrifugation. Xylanase activities of the supernatants were measured with $100 \mu \mathrm{L}$ of $2 \%$ soluble beechwood xylan in $1 \mathrm{~mL}$ of $20 \mathrm{mM}$ citrate buffer at $50{ }^{\circ} \mathrm{C}$ for $30 \mathrm{~min}$. The xylanases in the pellet fractions of two fungal species were dissociated with $300 \mu \mathrm{L}$ of dissociation buffer. The control was prepared with $20 \mu \mathrm{L}$ of the cellulase cocktail of $T$. reesei or $25 \mu \mathrm{L}$ xylanase solution of T. lanuginosus in the dissociation buffer $(100 \mu \mathrm{L} \mathrm{10 \%} \mathrm{SDS,} 100 \mu \mathrm{L}$ protein sample buffer, and adjusting to $300 \mu \mathrm{L}$ final volume with distilled water). The samples were loaded on the SDS-PAGE containing $30 \mu \mathrm{L} \mathrm{mL}^{-1}$ of $2 \%$ soluble beechwood xylan. The volumes were $1,2.5$, and $5 \mu \mathrm{L}$ for the control (1/2 diluted), and 5,10, and $20 \mu \mathrm{L}$ for the lignin adsorption samples for T. reesei xylanase. For the xylanase of T. lanuginosus, the volumes were $2.5,5$, and $10 \mu \mathrm{L}$ for 
the control (1/10 diluted), and 2.5, 5, and $10 \mu \mathrm{L}$ for the adsorption samples. Zymogram analysis of samples was performed following the procedure described above.

\subsection{Adsorption of Mannanase in the Cellulase Cocktail Obtained from T. reesei}

Analysis of adsorption of mannanase onto lignin was conducted using the zymogram procedure. The procedure for the preparation of the samples and control was the same as that used for EGs and xylanases. The SDS-PAGE was performed with $50 \mu \mathrm{L} \mathrm{mL}^{-1}$ of $0.5 \%$ glucomannan. The loading volumes are 5,10 , and $20 \mu \mathrm{L}$ for the control (1/10 diluted), and 20,30 , and $40 \mu \mathrm{L}$ for the samples. The subsequent experiment steps were as described above for EGs and xylanase.

\section{Result and Discussion}

\subsection{Adsorption of Extracellular Enzymes of T. reesei onto Lignin}

Lignin is synthesized through the radical coupling of the monolignols ( $p$-coumaryl, coniferyl, and sinapyl alcohol), which results in generation of three subunits termed $p$-hydroxyphenyl (H), guaiacyl (G), and syringyl (S). These subunits are then randomly incorporated into the lignin polymer [22]. Table 1 shows the composition ratio (\%) of the three subunits of lignin in different types of lignocelluloses. The lignin of poplar is composed of $61.9 \%$ syringyl (S), 37.8\% guaiacyl (G), $0.3 \%$ p-hydroxyphenyl $(\mathrm{H})$ subunits, showing a $1.64 \mathrm{~S} / \mathrm{G}$ ratio [23]. Pine lignin contains $1.7 \% \mathrm{H}, 98.3 \% \mathrm{G}$, and $0 \% \mathrm{~S}$ subunits. Corn and Arabidopsis lignin are composed of 58.9/38.3\% S and 20.1/77.1\% G units, respectively. Both lignin types include an $\mathrm{H}$ subunit at a $2.8 \%$ rate. Accordingly, these two lignin types have $\mathrm{S} / \mathrm{G}$ ratios of 1.54 and 0.26, respectively. Sewalt et al. (1997) reported that reduction in enzyme activity on pine, poplar, and mixed hardwood lignin is induced by high rates of free phenolic hydroxyl groups, high molecular weight, and high methoxy group content compared to barley straw lignin [24]. Corn stove lignin with high $\mathrm{G}$ unit content also allows adsorption of significantly higher levels of $\mathrm{CBH} 1$ and xylanase compared to the lignin of the herbaceous plant kenaf, Arabidopsis, and its ferulate-5-hydroxylase mutant. The lignin of pine softwood consists of a $95 \% \mathrm{G}$ subunit and also adsorbs xylanase and CBH1 at remarkable rates (45\% and $35 \%$, respectively) [18].

The types of lignin, enzymes, and the choice of pre-treatment method affect ligninenzyme interactions. The lignin from diluted acid pretreated creeping wild ryegrass was shown to yield the highest level of adsorption of cellulase (Celluclast $1.5 \mathrm{~L}$ ) and $\beta$-glucosidase (Novozyme 188), followed by the lignin from liquid hot water-pretreated mixed hardwood chip with a cellulase cocktail (Cellic Ctec 2, T. reesei), the lignin from diluted acid or steam explosion-pretreated corn stove or rice straw with cellulase (accellerase 1000, T. reesei), sulfite-pretreated lodgepole pine lignin with cellulase (Celluclast 1.5L), and organosolv-pretreated lodgepole pine lignin with cellulase (Celluclast 1.5L, T. reesei) [25]. Organosolv pretreatment produces a relatively pure, unaltered, and high-quality lignin with low molecular weight, and thereby leads to lower levels of lignin-enzyme interaction [26].

Here, lignin of oak, pine, rice straw, and kenaf biomass were isolated using popping pretreatment, milled, and subjected to enzymatic hydrolysis, without any chemical modification of the lignin structure. Lignocelluloses of hardwood, softwood, and herbaceous plants are composed of $15-35 \%$ lignin, $32-55 \%$ cellulose, $15-40 \%$ hemicellulose [27]. Hardwood lignin is composed of $25-50 \%, 0-8 \%$, and $46-75 \%$ G, $H$, and S subunits, respectively [28]. Pine lignin contains $1.7 \% \mathrm{H}, 98.3 \% \mathrm{G}$, and no $\mathrm{S}$ subunit [23]. The lignin of rice straw was found to be composed of $71 \%, 5 \%$, and $24 \% \mathrm{G}, \mathrm{H}$, and $\mathrm{S}$ subunits, respectively. Furthermore, $\beta-O-4^{\prime}$ alky-aryl ethers are present at $78 \%$, and $10-12 \%$ of the linkage dimers are acylated [29]. The kenaf lignin is composed of $40.9 \%, 1.0 \%$, and $58.1 \% \mathrm{G}, \mathrm{H}$, and S subunits, respectively [30]. Guo et al. (2014) previously suggested that the presence of a phenolic hydroxyl group affects lignin-enzyme interaction in corn stove and kenaf lignocellulose, and the S/G ratios affects lignin adsorption on cellulase when Arabidopsis and its ferulate-5-hydroxylase mutant were compared, except for pine lignin, which is intrinsically composed of high rates of $\mathrm{G}$ subunits [18]. 
Table 1. Chemical composition of lignin subunits in different types of plants.

\begin{tabular}{|c|c|c|c|c|c|}
\hline \multirow[b]{2}{*}{ Biomass } & \multicolumn{4}{|c|}{ Chemical Composition (\%) } & \multirow[b]{2}{*}{ Ref. } \\
\hline & Guaiacyl Unit (G) & $\begin{array}{c}p \text {-hydroxyphenyl } \\
\text { Unit (H) }\end{array}$ & Syringyl Unit (S) & S/G Ratio & \\
\hline Hardwood & $25-50$ & $0-8$ & $46-75$ & $1.50-1.84$ & [28] \\
\hline Populus tremuloides & 37.8 & 0.3 & 61.9 & 1.64 & [23] \\
\hline Quercus suber & 44 & 1 & 55 & 1.2 & [31] \\
\hline Eucalyptus globulus & 10 & 1 & 39 & 3.8 & [31] \\
\hline Softwood & $>95$ & $<5$ & 0 & - & [28] \\
\hline Pinus daeda & 98.3 & 1.7 & $0-1.3$ & - & [23] \\
\hline \multicolumn{6}{|l|}{ Herbaceous plants } \\
\hline Rice straw & 71 & 5 & 22 & 0.31 & [29] \\
\hline Kenaf & 40.9 & 1.0 & 58.1 & 1.40 & [30] \\
\hline Corn stove & 42.2 & 44.9 & 12.9 & 0.31 & [32] \\
\hline Arabidopsis & 77.1 & 2.8 & 20.1 & 0.26 & [23] \\
\hline
\end{tabular}

We also found that oak lignin showed higher adsorption capacity than other lignin types, with $40 \%$ adsorption capacity at $20 \mathrm{mg} \mathrm{mL}^{-1}$ lignin concentration (Figure 1 ). Rice straw lignin showed adsorption of $11-28 \%$ of cellulase, and thereby showed the lowest adsorption capacity. The adsorption capacities of the lignin decreased in the following order: oak $>$ pine $\geq$ kenaf $>$ rice. Hardwood oak lignin showed $5 \%$ more adsorption than softwood pine, and rice straw lignin with a $71 \% \mathrm{G}$ subunit showed the lowest rates of cellulase adsorption. These results are in contrast to previous findings, where pine lignin was reported to show $20 \%$ higher enzyme adsorption than aspen lignin [18], yet in agreement with findings of Sewalt et al. (1997) [24]. This indicates that many other factors (e.g., physiochemical properties of lignin and enzymes, and the reaction conditions) and interdependencies between these factors affect adsorption of cellulase enzymes onto lignin [33]. Hence, CBHs, Cel7B, Cel3A, XYLIV, and Man5A in a cellulase cocktail of $T$. reesei were separately investigated, as presented in the following sections, to determine the interactions of woody and herbaceous lignin with a single type of enzyme.
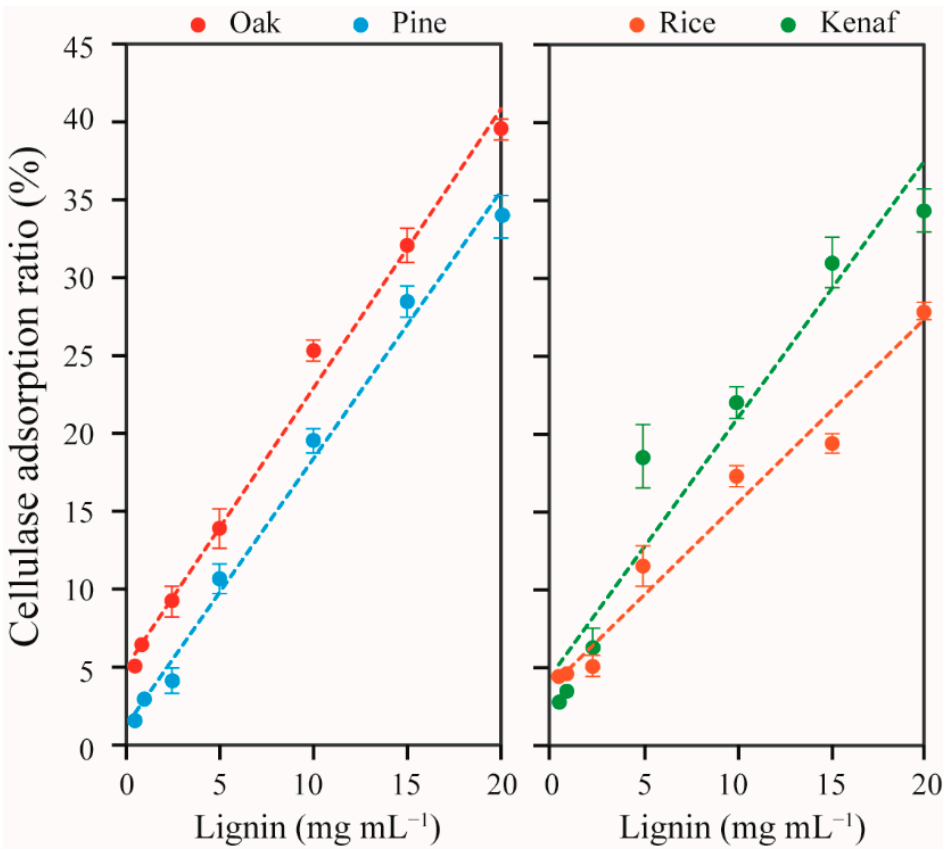

Figure 1. Rates of adsorption of extracellular enzyme onto lignin. Lignin isolated from oak, pine, rice straw, and kenaf were incubated in $1 \mathrm{~mL}$ of $20 \mathrm{mM}$ citrate buffer (pH 5.0) with cellulase cocktail of T. reesei. 


\subsection{Lignin Adsorption on Cellobiohydrolases (CBHs) and Individual Extracellular Enzyme of T. reesei}

Cellulolytic enzymes produced by $T$. reesei are composed of two cellobiohydrolases (CBHs: Cel7A and Cel6A), six endoglucanases (EGs), and small amounts of other enzymes such as $\beta$-glucosidase, six xylanase types (XYLI VI), $\beta$-xylosidase, xyloglucanase, and mannanase [34-37]. The $\mathrm{CBH}_{\mathrm{f}}$ (full length of cellobiohydrolases) consists of a catalytic domain $(\mathrm{CD})$ and a carbohydrate binding motif $(\mathrm{CBM})$ and cleaves off cellobiose units from the reducing and non-reducing ends. The $\mathrm{CBH}_{\mathrm{f}}$ and $\mathrm{CD}$ account for $68-78 \%$ of the total secretome of T. reesei [36]. We observed adsorption of CBHs and CD onto lignin on SDS-PAGE gels stained with Coomassie brilliant blue R-250 (Figure 2). The band corresponding to a molecular weight of $55 \mathrm{kDa}$ indicates $\mathrm{CBH}_{\mathrm{f}}$, whereas $\mathrm{CD}$ is observed on the band corresponding to a molecular weight of $48 \mathrm{kDa}$, accounting for $30.76 \%$ of the total $\mathrm{CBH}$ content (including $\mathrm{CBH}_{\mathrm{f}}$ and $\mathrm{CD}$ ). Adsorptions of $\mathrm{CBH}_{\mathrm{f}}$ onto lignin were found to be approximately $12-15 \%$ with oak and kenaf, and $7-8 \%$ with pine and rice lignin. The adsorption affinities decreased in the following order: oak $>$ kenaf $>$ rice $>$ pine lignin. $C D$ was found to be adsorbed at a rate approximately 2-5 times higher in pine and rice than in oak and kenaf lignin. The adsorption affinities of $\mathrm{CD}$ onto the lignin were found to be in the following decreasing order: pine $>$ rice $>$ oak $>$ kenaf lignin. This is consistent with the $\mathrm{G}$ unit ratios of these lignin types.

A
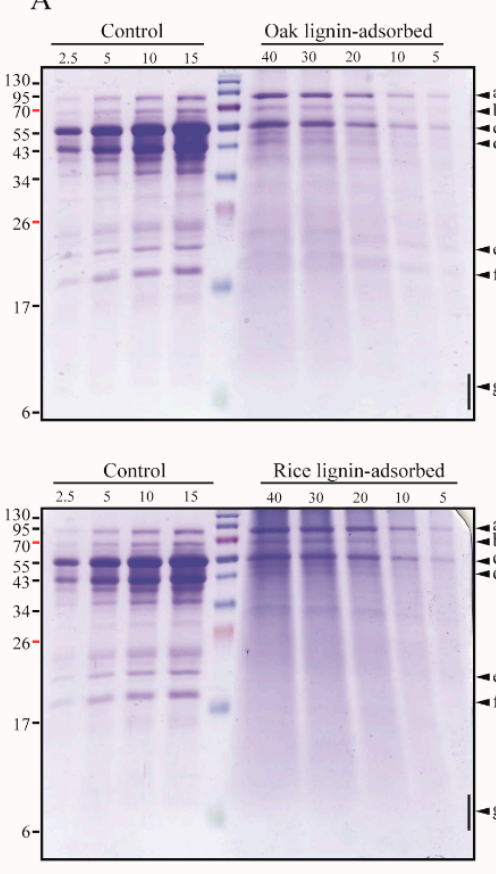
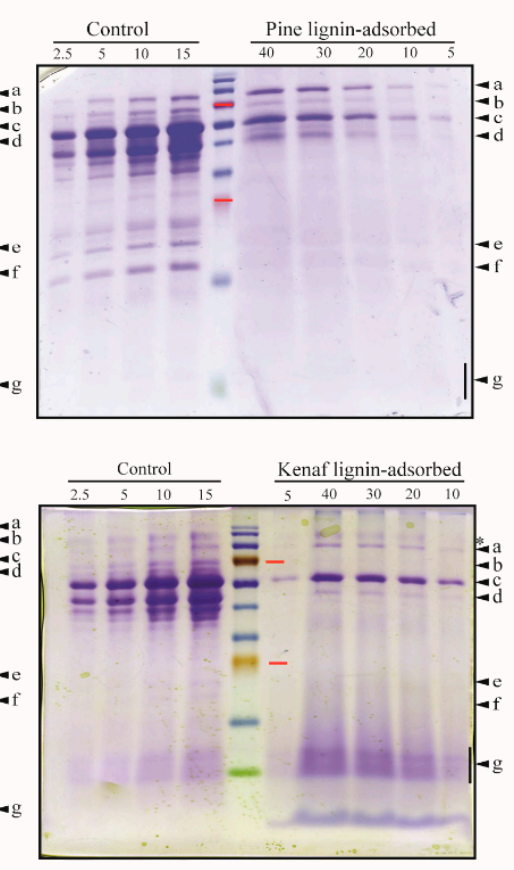

B
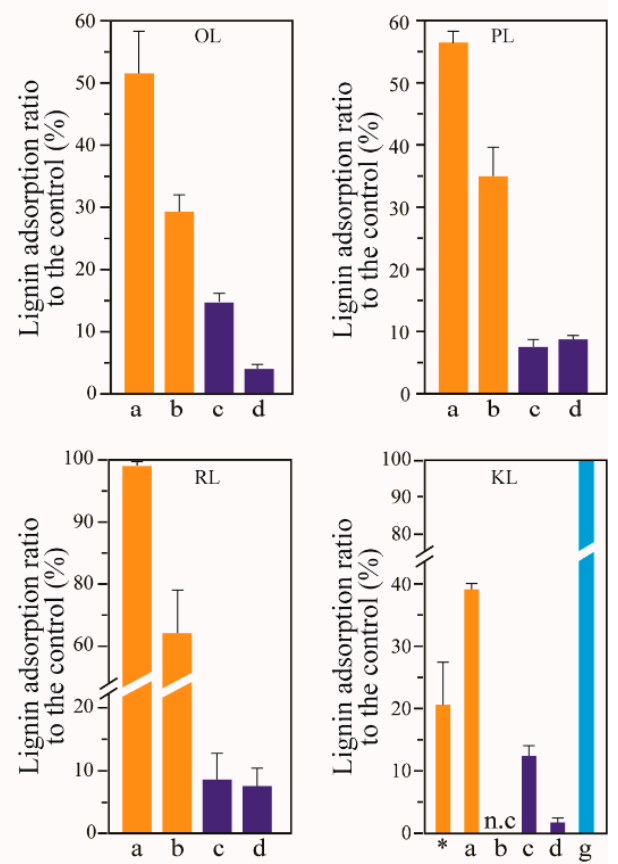

Figure 2. Adsorption of $\mathrm{CBHs}$ and high molecule weight protein in the cellulase of $T$. reesei onto lignin. (A) The proteins dissociated from $10 \mathrm{mg} \mathrm{mL}^{-1}$ lignins were separated via SDS-PAGE and stained with Coomassie blue and (B) the bands were quantified by analyzing band intensities. The numbers on the upper side of the gel indicate loading volumes $(\mu \mathrm{L}){ }^{*}, 95 \mathrm{kDa}$ (predicted to $\beta$-xylosidase or $\beta$-xyloglucanase); a, $81 \mathrm{kDa}$ (Cel3A: $\beta$-glucosidase, $p=0.010) ; \mathrm{b}, 70 \mathrm{kDa}(p=0.333) ; \mathrm{c}, 55 \mathrm{kDa}$ (Cel7A and Cel6A, $p=0.004) ; \mathrm{d}, 45 \mathrm{kDa}$ (CD: Catalytic domain of CBHs, $p \leq 0.001$ ); e and f, xylanases (XYNI and XYNII); g, low molecular weight proteins (6 10 kDa); n.c, not calculated. OL, oak lignin; PL, pine lignin, $R L$, rice straw lignin; KL, kenaf lignin.

Hydrophobic interactions between enzyme and lignin have also been identified as a major driving force of enzyme adsorption onto lignin [9,38,39]. CBM1s (CBM family 1 ) of Cel7A and Cel6A have a flat hydrophobic surface that interacts with the hydrophobic surface of the crystalline cellulose [40]. Based on the results of chemical shift changes of amino 
acids (G6 and Q7) on the flat plane surface of CBM1, Cel7A was found to prefer to interact with hardwood lignin (Eucalyptus globulus) compared to softwood Cryptomeria japonica. This is in line with our results.

Proteins with molecular weights above $70 \mathrm{kDa}$ were found to be adsorbed at significantly higher rates (30-100\%) than CBHs and CD (1-15\%). In particular, 80-90 kDa proteins were found to be adsorbed onto rice lignin at rates of $97.7-99.5 \%$. The sizes of secreted proteins of $T$. reesei, namely swollenin $(80 \mathrm{kDa}), \beta$-glucosidase (Cel3A, $81 \mathrm{kDa})$, and endoglucanase (Cel74A, $87.1 \mathrm{kDa})$ correspond to the size of the observed bands [36]. Hydrophobic patch scores on the enzyme structure also correlate with enzyme-lignin adsorption [9]. Accordingly, $\beta$-glucosidase (Bgl1) of A. niger has the highest hydrophobic patch score (45.9) compared to enzymes such as Cel7A (13.3), acetyl xylan esterase (9.1), and endoxylanase $(0.8)$ of $T$. reesei. No scores of a hydrophobic patch on $\beta$-glucosidase of $T$. reesei have been obtained. However, the $\beta$-glucosidase of $A$. niger was found to exhibit less adsorption onto lignin than $\beta$-glucosidase of $T$. reesei [41]. The extracellular $\beta$-glucosidase, Cel3A, accounts for $1.38 \%$ of total secreted proteins [36] and displays high adsorption rates onto the different types of lignin (Figure 2). These results thus indicate that the bands shown in Figure 2 correspond to $\beta$-glucosidase Cel3A ( $81 \mathrm{kDa}$ ). Two proteins with approximately 20 and $23 \mathrm{kDa}$ molecular weights were found to be adsorbed at higher rates onto lignin of woody plants (oak and pine) than that of herbaceous plants (rice and kenaf). These may correspond to xylanases XYNI and XYNII. Proteins with lower molecular weights ranging from 6 to $10 \mathrm{kDa}$ observed with kenaf lignin were also found to be adsorbed at $100 \%$. Further studies are required to more clearly identify these proteins.

\subsection{Adsorption of Endoglucanases onto Lignin}

Endoglucanases (Endo-1,4- $\beta$-D-glucanases, EGs) randomly cleave internal $\beta$-1,4glucoside bonds in the cellulose chain, and account for $8.46-17.4 \%$ of the secreted proteins of T. reesei, which were found to be composed of $5-10 \%$ Cel7B, $1.26-2.40 \%$ Cel7B, $2 \%$ Cel5A, $0.05-1.96 \%$ Cel12A, and 0.18-0.78\% Cel61A [36,42]. The activity of EGs accelerates the saccharification rate with $\mathrm{CBHs}$, and due to generation of more reducing and non-reducing ends of cellulose chains.

The EGs produced by $T$. reesei have been classified into two glycoside hydrolysis family 5 proteins $(\mathrm{GH} 5)$, Cel5A $(48 \mathrm{kDa})$ and Cel5B $(46.8 \mathrm{kDa})$, a GH 7 protein Cel7B (55 kDa), a GH 12 protein Cel12A (26 kDa), a GH 45 protein (Cel45A, $24.4 \mathrm{kDa})$, two GH 61 proteins, Cel61A (35.5 kDa) and Cel6B $(26 \mathrm{kDa})$, a GH 74 protein Cel74A $(87.1 \mathrm{kDa})$, and an endoglucanase candidate enzyme ( $36 \mathrm{kDa})$ [36]. We observed activities of EGs on CMC substrate (these EGs are referred to as the enzymes that are active on CMC) in SDS-PAGE and zymogram assay results (Figure 3A). These activities are manifested on bands including proteins such as E1 ( 100 kDa), E2 (Cel74A, $87 \mathrm{kDa}), \mathrm{E} 3(\mathrm{Cel} 7 \mathrm{~B}, 55 \mathrm{kDa}), \mathrm{E} 4$ (Cel5A, $48 \mathrm{kDa})$, E5 $(\sim 40 \mathrm{kDa})$, E6 $(\sim 30 \mathrm{kDa}), \mathrm{E} 7(\sim 20 \mathrm{kDa})$, E8 $(\sim 15 \mathrm{kDa})$, and E9 $(\sim 10 \mathrm{kDa})$. The ratio of each enzyme in total endoglucanase content was determined by analyzing band intensities on the gel. E3 and E4 were found to account for $48.01 \%$ and $24.61 \%$ of the total EG activity, respectively. By comparison, E1, E2, E5, E6, E7, E8, and E9 were found to be responsible for $7.45 \%, 3.13 \%, 5.33 \%, 2.60 \%, 2.18 \%, 4.63 \%$, and $2.06 \%$ of the total activity, respectively (Figure $3 \mathrm{~A}$ ).

The EG adsorption onto lignin of oak, pine, rice, and kenaf was determined using the following equation: [EGs adsorption] $=$ [Total EGs activity] - [Free EGs activity in supernatant after lignin adsorption]. Surprisingly, EG activity was found to be elevated by $10 \sim 25 \%$ after adsorption onto lignin (Figure 3B). EG activity on CMC in the cellulase cocktail is connected to $\mathrm{CBH}$ and $\beta$-glucosidase, and is directly dependent on $\beta$-glucosidase to accelerate the hydrolysis rate of the substrate [43]. The underlying reason for this increased activity of EGs after adsorption onto lignin is discussed in the following section with $\beta$-glucosidase. Zymogram assay is useful to measure adsorption of specific endoglucanase types with different binding affinities to lignin without $\mathrm{CBHs}$ and $\beta$-glucosidase activity. Zymogram results are shown in Figure 3C-G. The major endoglucanase, E3, was found 
to be adsorbed less than CBHs with similar molecular weight and cellulose binding motif 1 family (CBM1), and showed two times higher adsorption in lignin of the herbaceous plants rice and kenaf. Enzymes E1 and E2 with high molecular weights were found to be adsorbed onto lignin at rates of 2.15-3.1\% and 1.5-6.29\%, respectively. Adsorption of E2 was also found to be 2-4 times higher compared to that of herbaceous plants. Finally, adsorption of E6 was found to be 2 times higher onto oak lignin compared to other lignin types.

A

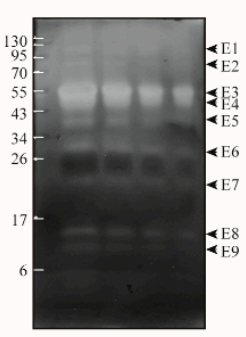

E

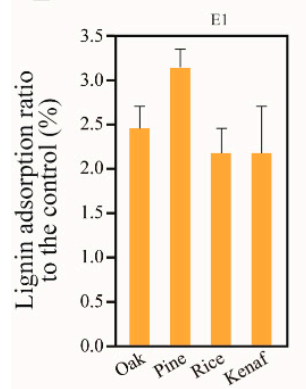

B
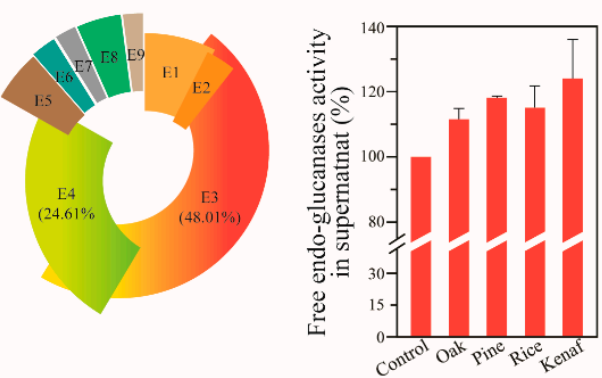

E2
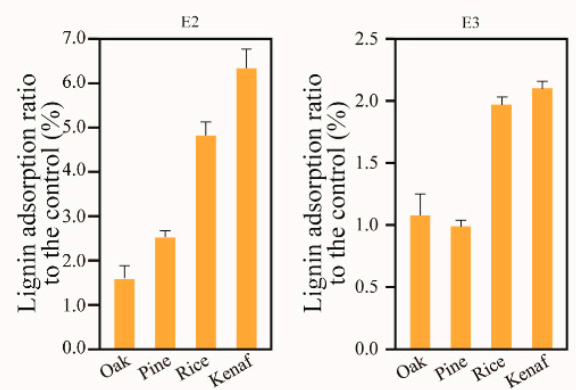

$\mathrm{C}$

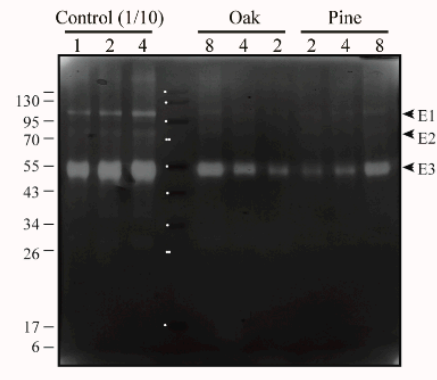

F

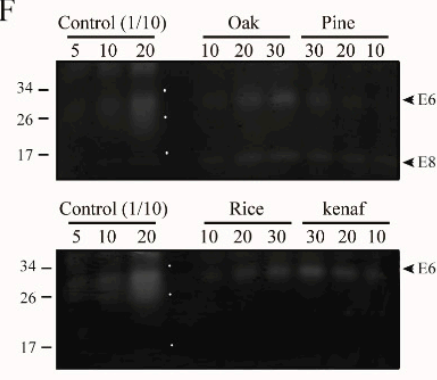

$\mathrm{D}$

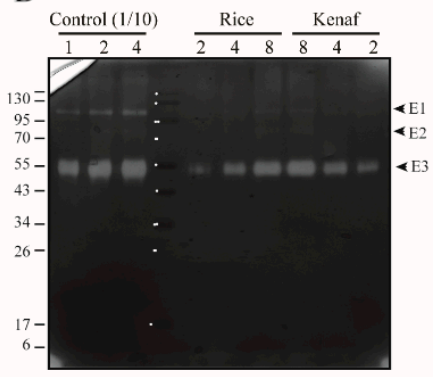

G

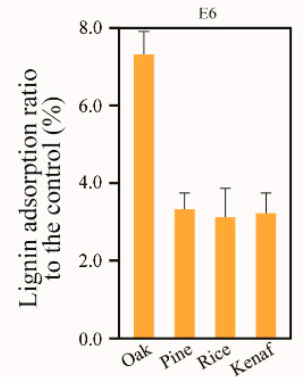

Figure 3. Adsorption of endoglucanases (EGs) in cellulase cocktail of T. reesei onto lignin. (A) Endoglucanases in the cellulase were quantified by measuring their activities on CMC substrate in SDS-PAGE. The activity ratios were as follows: E1 (7.45\%), E2 (3.13\%), E3 (48.01\%), E4 (24.61\%), E5 (5.33\%), E6 (2.60\%), E7 (2.18\%), E8 (4.68\%), and E9 (2.06\%). (B) Adsorption of EGs onto lignin was measured by comparing the activities of EGs in the supernatants to that of the control following lignin-enzyme precipitation $(p=0.121)$. (C-G) Adsorption of EGs onto lignin was analyzed by zymogram assay using CMC substrate in SDS-PAGE, for lignin of the woody plants oak and pine (C) and the herbaceous plants rice straw and kenaf (D). The band intensity was analyzed for quantification and comparison of the adsorptions of EGs (E,G). The zymogram activity of E6 was shown (F). The numbers on the upper side of the gel indicate loading volumes ( $\mu \mathrm{L}) . \mathrm{E} 1, \sim 100 \mathrm{kDa}$ $(p=0.070)$; E2, $87 \mathrm{kDa}(\mathrm{Cel74A}, p=0.022) ; \mathrm{E} 3,55 \mathrm{kDa}(\mathrm{Cel7B}, p=0.006) ; \mathrm{E} 4,48 \mathrm{kDa}(\mathrm{Cel5A}) ; \mathrm{E} 5$, $\sim 40 \mathrm{kDa}$; E6, $\sim 30 \mathrm{kDa}(p=0.004)$; E7, $20 \mathrm{kDa}$; E8, 15 kDa; E9, 10 kDa.

\subsection{Adsorption on $\beta$-Glucosidases onto Lignin}

Ten $\beta$-glucosidase isozyme (Bgls) genes of $T$. reesei exist according to the $T$. reesei genome database v.2.0 and Carbohydrate-Active Enzymes (CAZy) database. The Bgls include two isozymes (Cel1A and Cel1B) of the glycoside hydrolase family 1 (GH 1) and eight in the GH 3 family (Cel3A, B, C, D, E, F, G, H) [44]. The Bgls can be also classified according to the protein destinations into two groups: extracellular Bgls including Cel3A (81 kDa), Cel3B (108 kDa), Cel3F (139 kDa), and Cel3G (129 kDa); and intracellular Bgls including Cel1A (BglII, $55 \mathrm{kDa})$, Cel1B (58 kDa), CelC (100 kDa), Cel3D (90 kDa), and Cel3E (104 kDa). Among these, Cel3A has been quantified in the secretome of T. reesei and was found to account for $1.38 \%$ of total secreted proteins [33]. Cel3A was also shown to have high affinities for cellotriose, sophorose, and laminaribiose. Cel3B has the highest specific activity on cellobiose, followed by Cel1A and Cel3A. Cel1A of the Bgls was found to have the highest affinity for cellobiose and tolerance to the end product glucose [44]. This 
is advantageous to enhance the conversion rate of cellobiose to glucose by mutagenesis against end-product inhibition [45].

End-product inhibition is known to cause reduction in the enzymatic hydrolysis rate. Cellobiose is a particularly strong inhibitor of Cel7A, and leads to the loss of $50 \%$ of the enzyme activity at $19 \mathrm{mmol} \mathrm{L}^{-1}$ cellobiose concentration, whereas Cel6A loses $25 \%$ of its activity at $42 \mathrm{mmol} \mathrm{L}^{-1}$ cellobiose concentration [46]. The $\beta$-glucosidase of $T$. reesei loses its activity upon adsorption onto lignin isolated from liquid hot water-pretreated hardwoods, whereas the activity is maintained in the case of Bgls of $A$. niger [41]. This is considered to be due to the adsorption of $\beta$-glucosidase onto lignin, leading to the increase in cellobiose concentration in the early stages of enzymatic hydrolysis and resulting in the severe reduction in the hydrolysis rate. Supplementation with $\beta$-glucosidase of $A$. niger avoids the reduction in the hydrolysis rate due to lignin adsorption.

An adsorption experiment of $\beta$-glucosidases in the cellulase of $T$. reesei onto lignin was performed at $50{ }^{\circ} \mathrm{C}$ for $1 \mathrm{~h}$ in $1 \mathrm{~mL}$ of $20 \mathrm{mM}$ citrate buffer including $10 \mathrm{mg} \mathrm{mL}^{-1}$ lignin. The activities of free enzymes in the supernatants after adsorption onto lignin were measured with substrates $p$ NPG or cellobiose. The $\beta$-glucosidases were found to be adsorbed at the highest rates onto kenaf lignin (Figure 4). However, when glucose yields are compared, different rates of adsorptions of $\beta$-glucosidase isozymes are observed. Here, the highest conversion rate of cellobiose to glucose was shown in the fraction of rice and kenaf lignin adsorption, although the lowest cellulose consumption was shown, which indicated that the $\beta$-glucosidase isozyme possessing the transglycosylation function was dominantly adsorbed by rice and kenaf lignin. Previous reports indicated that Cel3A has a higher $\mathrm{K}_{\text {cat }}\left(\mathrm{S}^{-1}\right)$ value on cellobiose, and higher transglycosylation activity on cellobiose to cellotriose than those of Cel3B [44]. The higher hydrophobicity and pI point of cellulolytic enzymes contribute to higher lignin adsorption $[9,30,38]$. Cel3A has also been characterized to have a higher isoelectric point (8.5) and hydrophobicity value $(-0.163)$ than those of Cel3B (5.73 and -0.317 , respectively) [41]. These results indicate that Cel3A was dominantly adsorbed onto the lignin of rice and kenaf under a $\mathrm{pH} 5.0$ condition and resulted in lower cellulose consumption and a higher glucose yield in the fraction of the herbaceous lignin. This result also explains why, in Figure 4B, EG activities after lignin adsorption are increased.

Aspergillus niger is one of the most efficient producers of $\beta$-glucosidase. To date, $17 \beta$-glucosidase encoding genes have been identified in the $A$. niger genome [47], and even more $\beta$-glucosidase genes have been estimated to exist (JGI MycoCom, https: / / mycocosm. jgi.doe.gov / Aspni7 / Aspni7.home.html, accessed on 1 December 2021). These enzymes can be classified to belong to the GH family 1 and/or GH 3 [48]. Eight enzymes were found to be secreted into the extracellular environment [47]. $\beta$-glucosidases also have two times higher hydrolytic activity on cellobiose than on $p$-NPG according to the supplier's reference and Seidle et al. (2004) [49].

Adsorption of $A$. niger $\beta$-glucosidase onto lignin was performed at $50{ }^{\circ} \mathrm{C}$ for $1 \mathrm{~h}$ in $1 \mathrm{~mL}$ of $20 \mathrm{mM}$ citrate buffer (pH 5.0) including $10 \mathrm{mg} \mathrm{mL}^{-1}$ lignin. $\beta$-glucosidases adsorbed onto lignin were separated via SDS-PAGE (Figure 4C-E). The band B4 (approximately $56 \mathrm{kDa}$ ) included enzymes highly adsorbed onto the lignin structure at rates of $52-130 \%$. Two $\beta$-glucosidases of $A$. niger belonging to the GH family 1 and relatively small molecular weight $(54.2$ and $64 \mathrm{kDa})$ have been reported previously [47,50]. The genes encoding two $\beta$-glucosidases (Accession No: An03g03740 and An11g02100) were predicted to be secreted into the extracellular environment (BUSCA: http://busca.biocomp.unibo.it/, accessed on 1 December 2021); however, An03g03740 (designated Bg11B, $54.2 \mathrm{kDa}$ ) was also confirmed to be an intracellular protein in vivo in Saccharomyces cerevisiae [51]. Here, B4, an extracellular $\beta$-glucosidase belonging to the GH family 1 , is highly adsorbed onto lignin. Regarding $\beta$-glucosidases belonging to GH family 3 with higher molecular weights, of between 95 and $170 \mathrm{kDa}$ (B2 and B3), B2 was found to be adsorbed at $15-20 \%$ onto all lignin types except for kenaf lignin (3\%), and B3 was found to adsorbed onto lignin 0.5-4.2 times higher than the control sample. $\beta$-glucosidase $(\mathrm{Bgl1}, 117 \mathrm{kDa})$ of $A$. niger was also found 
to have the highest hydrophobicity patch score compared to serum albumin, Cel7A (cellobiohydrolase 1), Axe1 (acetyl xylan esterase), E1 (endoglucanase), XynA (endoxylanase), AbfB (arabinofuranosidase), and Xyn11 (endoxylanase) [9]. This result explains why B3 $(110 \mathrm{kDa})$ was found to be most adsorbed onto the lignin.

A

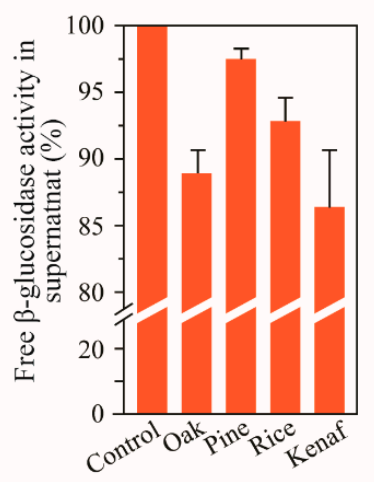

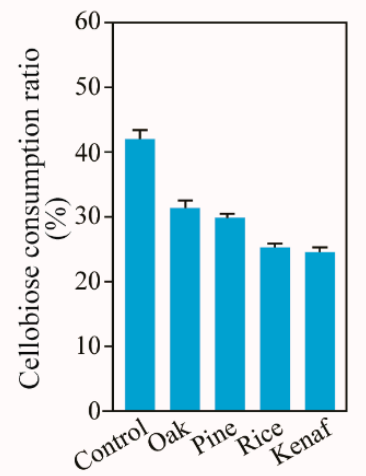

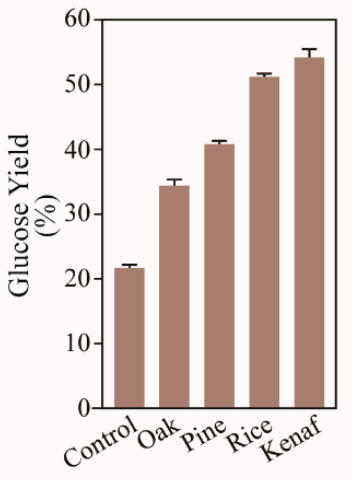

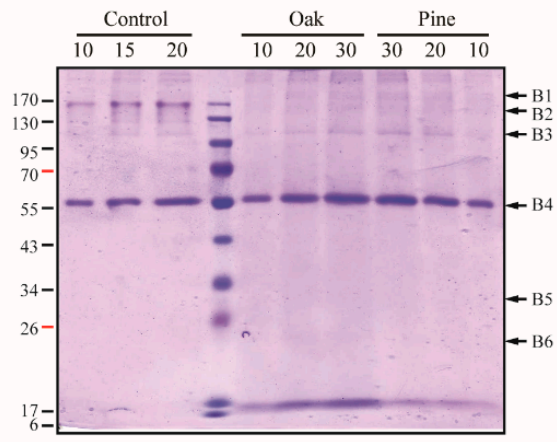

D

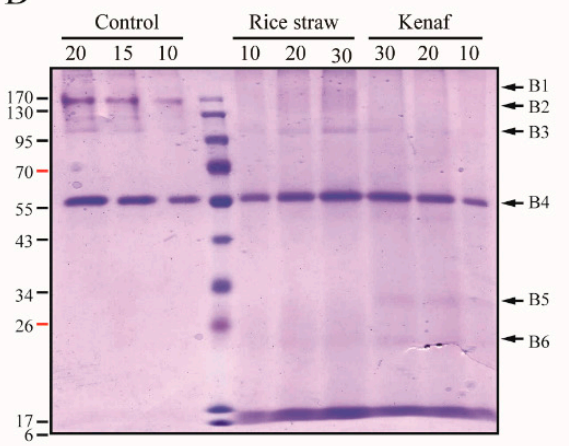

E

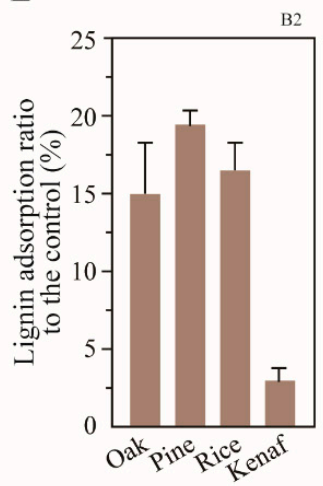

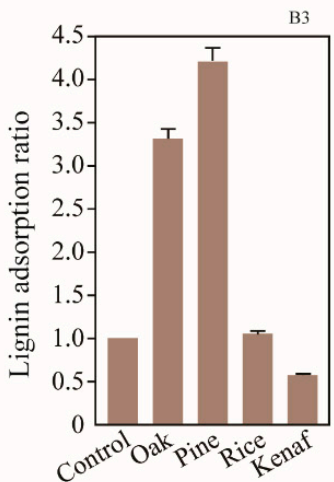

Figure 4. $\beta$-glucosidase inhibition upon adsorption onto lignin. $\beta$-glucosidases activities in T. reesei cellulase cocktail were measured via quantification of $p$ NPG (A) and cellobiose (B), and adsorption ratio was analyzed $(p=0.033)$. (B) Transglycosylation activity of $\beta$-glucosidases were observed to be high in the control, based on the observed correlation between cellobiose consumption $(p \leq 0.001)$ and glucose production $(p \leq 0.001)$. (C-E) Adsorption of A. niger $\beta$-glucosidase onto lignin was performed, and the enzymes dissociated from the lignin were loaded onto the SDS-PAGE gel (C,D), and band intensities were analyzed (E). B1 concentration was increased due to adsorption onto lignin, especially for oak and pine lignin. B2 and B3 corresponded to major bands of $\beta$-glucosidase belonging to GH family 3. The numbers on the upper side of the gel indicate loading volumes $(\mu \mathrm{L})$. B1: $190 \mathrm{kDa}$; B2: $160 \mathrm{kDa}(p \leq 0.001)$; B3: $110 \mathrm{kDa}(p=0.005)$; B4: $56 \mathrm{kDa}(p \leq 0.001)$; B5: $30 \mathrm{kDa}$; B6: $20 \mathrm{kDa}$.

\subsection{Xylanase Adsorption by the Lignins}

Hemicelluloses are heterogeneous polysaccharides composed of different combinations of sugar polymers such as xylans, arabinans, mannans, and galactans, depending on the source and type of lignocellulosic biomass [52]. The hemicellulose of hardwood is composed of 80-90\% O-acetyl-4-O-methylglucuronoxylan, 0.1-1\% arabinomethylglucurononxylan, and 1-5\% glucomannans. The main component of softwood hemicellulose is galactoglucomannan, which accounts for $60-70 \%$ of hemicellulose. Galactoglucomannan is followed by arabinomethylglucuronoxylan and methyglucuronoxylan, which account for $13-30 \%$ and $5-15 \%$ of the hemicellulose, respectively.

$\beta$-xylanases (Endo-1,4- $\beta$-D-xylanases) randomly cleave internal $\beta$-1,4-xylosidic bonds within the xylan structure, and account for $0.42 \%$ of the secreted proteins of T. reesei [36]. The composition of secreted $\beta$-xylanases was found to be composed of $0.25 \%$ XYNI (19 21 kDa), 
0.07\% XYNII (20 21 kDa), XYNIII (not measured, $38 \mathrm{kDa}), 0.10 \%$ XYNIV (55 kDa), XYNV (not measured, $21 \mathrm{kDa}$ ), and XYNVI (not measured, $57 \mathrm{kDa}$ ) [35-37,53]. Two xylanases (XYNI and XYNII) from the GH family 11 are known to be major xylanolytic enzymes of T. reesei. However, in this study we found the GH family 30 XYNIV was the main enzyme of xylanases in the cellulase cocktail of T. reesei in terms of activity on the soluble beechwood xylan (Figure 5).

A

D
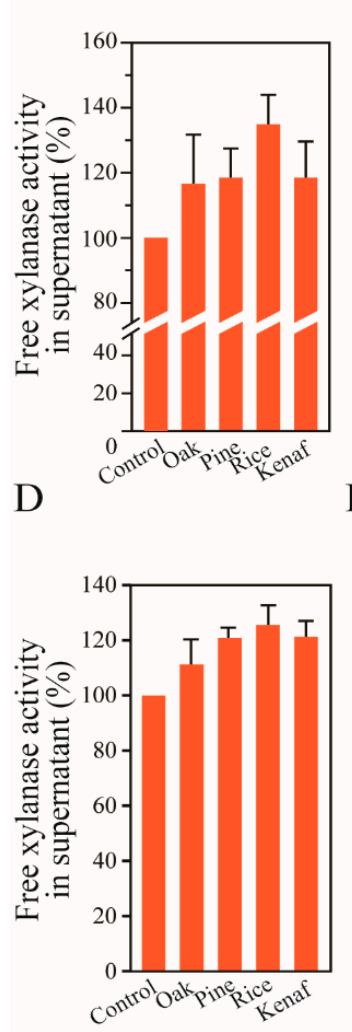

B

E

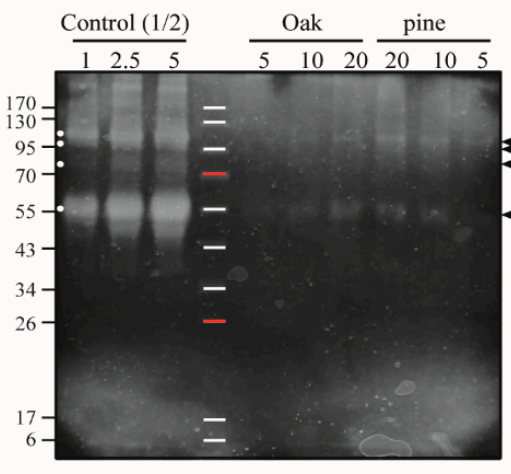

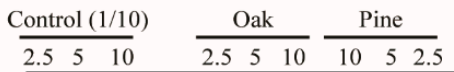

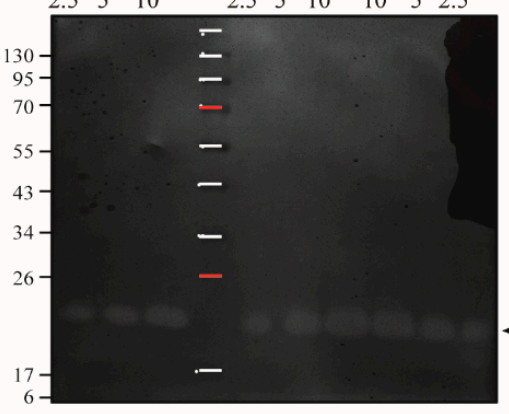

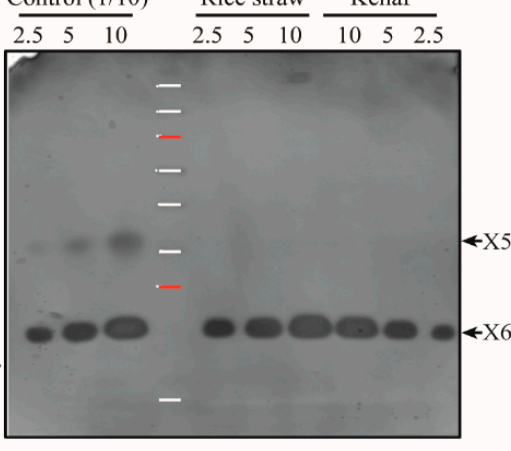

C

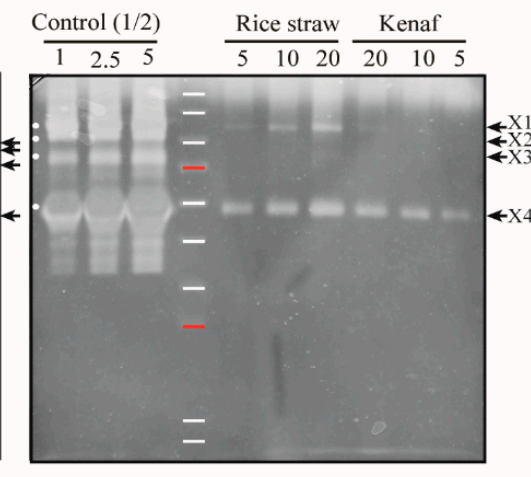

F
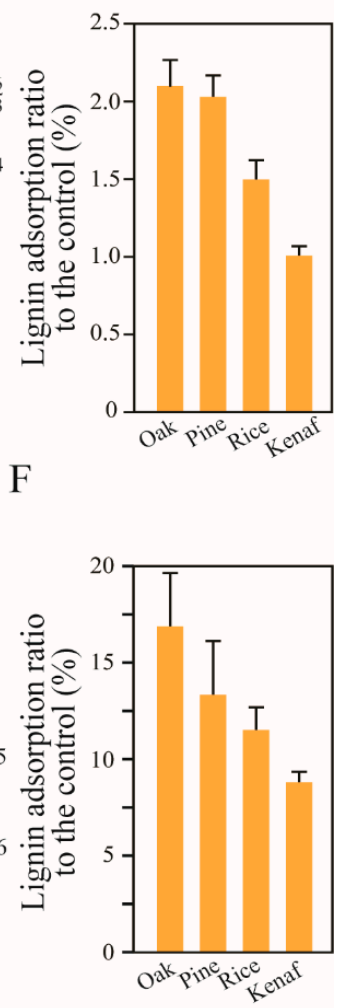

Figure 5. Adsorption of T. reesei and T. lanuginosus xylanases onto lignin. (A) Adsorption of xylanase in the cellulase cocktail of $T$. reesei onto lignin was determined by measuring the xylanase activity in the supernatant $(p=0.361)$ and $(\mathbf{B}, \mathbf{C})$ zymogram activity in the lignin pellet fraction on soluble beechwood xylan. Several bands indicating xylanase activity were observed on the gel at positions corresponding to approximately $110 \mathrm{kDa}(\mathrm{X} 1), 100 \mathrm{kDa}(\mathrm{X} 2)$, and $80 \mathrm{kDa}(\mathrm{X} 3)$. The band intensity of the major xylanase, XYNIV $(X 4,55 \mathrm{kDa})$ was determined $(p=0.001)$. Woody lignin of oak and pine were found to yield higher adsorption than herbaceous lignin of rice and kenaf. (D-F) Adsorption of T. lanuginosus onto lignin. The free xylanases in the supernatant were measured $(p \leq 0.001)$. The bands indicating xylanase $(23 \mathrm{kDa}, \mathrm{X} 6)$ were visible on SDS-PAGE gel containing beechwood xylan. Intensities of these bands were determined to quantify adsorption of the enzyme $(p=0.037)$. $\beta$-xylosidase (X5) was shown at the position of molecular weight $38 \mathrm{kDa}$ in the control sample. The numbers on the upper side of the gel indicate loading volumes $(\mu \mathrm{L})$.

Xylan derivatives formed in the early stages of enzymatic hydrolysis, especially xylooligomers, are strong inhibitors of cellulases Cel7A and Cel6A [54]. Guo et al. (2014) previously reported that the crude xylanase produced by Penicillium sp. was most adsorbed onto pine lignin and showed about $45 \%$ of inhibition. The adsorption ratios of different lignin types were arranged in the following decreasing order: pine > corn stove $>$ aspen $>$ kenaf [18]. Therefore, the reduction in endo- $\beta$-xylanase and $\beta$-xylosidase activities due to adsorption onto lignin is likely a severe problem hindering rapid and economic enzymatic saccharification for bioconversion. 
Activities of free xylanases in the control cellulase cocktail of T. reesei and in the supernatant obtained after centrifugation were measured (Figure 5A). The activities of free xylanases in the supernatants were unexpectedly increased for all lignin types. To confirm adsorption of xylanases onto lignin without enzyme dissociation, samples were incubated with soluble beechwood xylan, and xylanase activities were measured. The ratio of the activities of the adsorbed xylanase were found to be $6.5-8.5 \%$ with respect to the control. The free xylanase activity in the supernatant is due to the presence of $\beta$-xylosidase and various xylanolytic enzymes which correspond to several bands at molecular weights of approximately $110 \mathrm{kDa}(\mathrm{X} 1), 100 \mathrm{kDa}(\mathrm{X} 2)$, and $80 \mathrm{kDa}(\mathrm{X} 3)$ in Figure 5B. In addition, small molecular weight $\mathrm{XYNI}$ and $\mathrm{XYNII}$ have been known to be the main enzymes in terms of expression levels, and not detectable under the zymogram experimental conditions. The same result was also obtained for free xylanase activity after adsorption onto lignin for xylanase from T. lanuginosus (Figure 5D). This is not representative of adsorption of endo $\beta$-xylanases onto lignin. Zymogram activity results show the adsorption of a major xylanase, XYNIV, in Figure 5B,C. Accordingly, XYNIV was found to be adsorbed onto lignin at rates of $1-2 \%$, and kenaf lignin displayed the lowest binding affinity to the enzyme. This is consistent with the results of Guo et al. (2014) [18]. Lignin from woody plants were also found to allow adsorption of more XYNIV than those of herbaceous plants. X1 with a higher molecular weight was found to be adsorbed onto pine lignin more than oak lignin, and kenaf lignin yielded higher adsorption than rice straw lignin.

The xylanase of T. lanuginosus xylanase was used to estimate adsorption rates of xylanases with small molecular weights. Hemicellulase produced by T. lanuginosus is composed of $\beta$-xylanase (Xyn11A, GH 11, 24.3 kDa) and $\beta$-xylosidase (GH 43, 38.1 kDa) [55,56]. The $\beta$-xylanase is expressed at high quantities and shows high thermal stability; therefore, it is commercially useful. The small molecular weight xylanases, XYNI and XYNII, belonging to GH family 11 in the cellulase cocktail of $T$. reesei, have low activities on beechwood xylan, which renders measurement of the enzyme-lignin affinity difficult. The xylanase Xyn11A, from $T$. lanuginosus belonging to the same GH family and highly active on beechwood, can be surrogated for the XYNI and XYNII of T. reesei.

Adsorption of Xyn11A onto lignin was conducted, and supernatant and lignin pellet fractions were obtained. The xylanases on the different types of lignins were dissociated from lignin and loaded onto SDS-PAGE gels containing beechwood xylan for zymogram analysis. The xylanase with the molecular weight of approximately $23 \mathrm{kDa}$ was found to be adsorbed by up to $17.0 \%$ onto oak lignin. Oak lignin was followed by pine, rice straw, and kenaf lignin showing $13.4 \%, 11.6 \%$, and $9.0 \%$ adsorption onto lignin, respectively (Figure 5D,F). The single xylanase (Xyn11A) adsorption onto the lignin was shown to be 6.6-8.9 times higher than that of XYNIV in the cellulase cocktail of T. reesei. When the Xyn11A of T. lanuginosus is used to supplement the cellulase cocktail, the quantity of the enzyme that is adsorbed can be determined.

The free $T$. reesei and T. lanuginosus xylanase activities in the supernatants were observed to increase by $17-35 \%$ and $10-20 \%$ compared to the control, respectively. This is distinguishable from the different levels of increase between the xylanase activities of T. reesei and T. lanuginosus depending on the complexity of the enzyme components. There are many cellulolytic and helping enzymes containing carbohydrate binding modules (CBM1 is dominant) in the cellulase cocktail of $T$. reesei [53]. It cannot be ruled out that these enzymes bind other polysaccharides. Type B CBMs are known to be able to interact with cellulose and xylan substrates, and the CBM of endoglucanase of microorganisms in buffalo rumen can also bind diverse substrate polymers such as Avicel, birchwood xylan, mannan, lichenan, and raw starch [57]. The increase in the T. reesei xylanase activity after adsorption onto lignin may thus be considered to be induced by a reduction in the amounts of competitors such as the endoglucanases and helping enzymes containing CBMs. Moreover, the activity of the xylanase of $T$. lanuginosus may also have been induced by reduction in the masking effect on the substrate due to adsorption onto lignin [7]. This result and 
the adsorption rate of the xylanases are available to prepare a cost-efficient hydrolytic enzyme cocktail.

\subsection{Adsorption of Mannanase onto Lignin}

Endo-1,4- $\beta$-D-mannanase cleaves internal $\beta$-1,4-D-glycosidic bonds of the mannan backbone chain, and several enzymes, such as $\beta$-mannosidase, $\beta$-glucosidase, acetylmannan esterase, and $\alpha$-galactosidase, participate in the hydrolysis of galactoglucomannan in the hemicellulose of softwood [58]. $\beta$-mannanase was also reported to act synergistically with xylanase during the enzymatic hydrolysis of softwood [59-61].

A mannanase produced by T. reesei has been previously identified as Man5A (experimentally $53.6 \mathrm{kDa}$ ) or mannanase I (MANI, experimentally $53 \mathrm{kDa}$, accounting for $0.25 \%$ of the secreted proteins) containing CBM1 [36,62]. Here, a small amount of Man5A in the cellulase cocktail was adsorbed onto the woody lignin of oak and pine at rates of $1.21 \%$ and $1.74 \%$, and at $1.83 \%$ and $2.50 \%$ in the herbaceous lignin of rice and kenaf, respectively (Figure 6). The supplement including recombinant mannanase remarkably accelerated the saccharification rate of softwood [60], which implies that adsorption of mannanase onto lignin shows no synergistic effect in the early stages of hydrolysis, and results in severe retardation of saccharification.

A

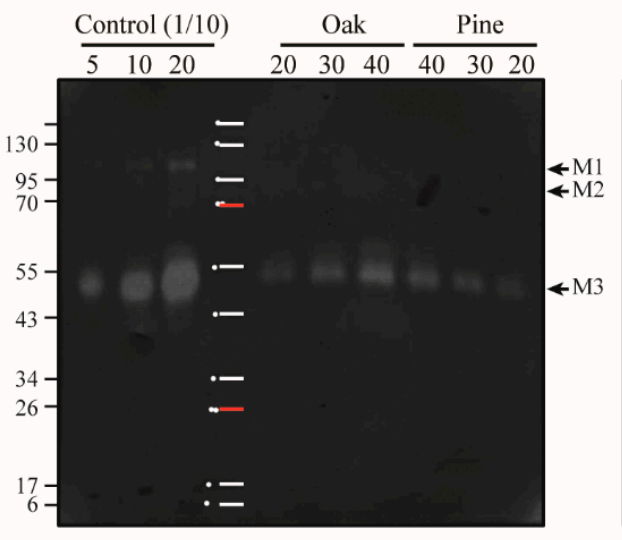

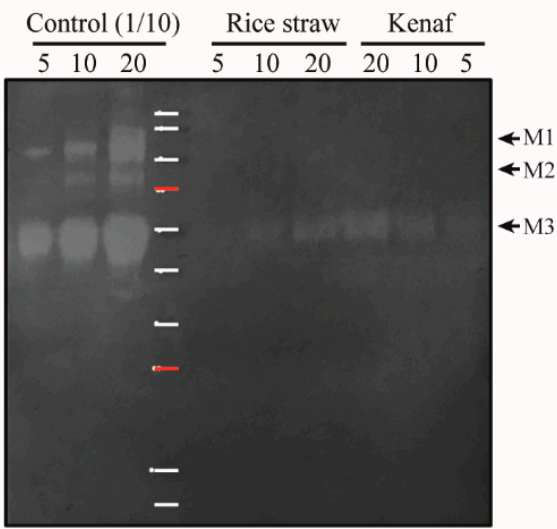

B

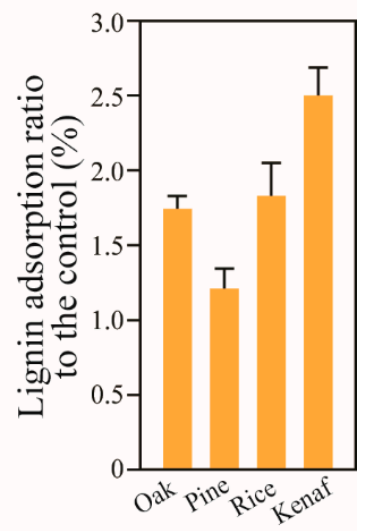

Figure 6. Adsorption of T. reesei mannanase onto lignin (A) Zymogram activity of mannanase adsorbed onto the lignin of oak, pine, rice straw and kenaf was assessed. The bands on SDS-PAGE containing glucomannan were observed at the $53 \mathrm{kDa}$ position (M3), which indicates that Man5A is the major mannanase. (B) The intensities of the bands (M3) were determined to compare ratios of adsorption with different types of lignin $(p=0.409)$. The numbers at the top of the gels represent the loading volume $(\mu \mathrm{L})$. The control was diluted $10 \times$. The two bands showing mannanase activity were observed at the positions corresponding to approximately 110 and $80 \mathrm{kDa}$, which are indicated with M1 and M2, respectively.

\subsection{Summary of Lignin Adsorption of Major Enzymes in the Cellulase Cocktail of T. reesei}

A comparative evaluation of adsorption of specific enzymatic species in the cellulase cocktail onto lignin was performed to analyze their levels of interaction with different types of lignin (Table 2). The absorption of the full-length CBHs (CD+CBM) was $97 \%$ and $43 \%$ higher onto the oak and kenaf lignin than the rice and pine lignin. The adsorption ratio indicates that the enzyme has higher affinity to the lignin having a higher $\mathrm{S} / \mathrm{G}$ ratio. Adsorption of $\mathrm{CD}$ was in the reverse order. The $\mathrm{CBM} 1$ of $\mathrm{CBHs}$ with high hydrophobicity contributed to higher binding affinities of oak and kenaf lignins. The Cel7B was adsorbed at higher levels onto lignins of herbaceous plants, whereas XYNIV was adsorbed at higher levels onto the lignin of woody plants. The $\beta$-glucosidase, Cel3A, was adsorbed onto rice lignin at high levels (approximately $95 \%$ ), at $51-57 \%$ onto the woody plant lignin, and at 
$19 \%$ onto the kenaf lignin. The high hydrophobicity of Cel3A also caused remarkable levels of adsorption onto lignin compared to other enzymes. Finally, kenaf lignin yielded the highest adsorption of mannanase.

Table 2. Rates of adsorption of the major enzymes in the cellulase cocktail produced by T. reesei onto different types of lignin.

\begin{tabular}{|c|c|c|c|c|c|}
\hline & \multirow{2}{*}{$\begin{array}{l}\text { Molecular Weight } \\
\text { (kDa) }\end{array}$} & \multicolumn{4}{|c|}{ Lignin Adsorption Rate (\%) } \\
\hline & & Oak & Pine & Rice Straw & Kenaf \\
\hline \multicolumn{6}{|l|}{ Cellobiohydrolase } \\
\hline $\mathrm{CD}^{1}+\mathrm{CBM}^{2}$ & $55 \mathrm{kDa}$ & $14.61 \pm 1.94$ & $7.40 \pm 1.63$ & $8.74 \pm 3.27$ & $12.52 \pm 2.69$ \\
\hline $\mathrm{CD}$ & $48 \mathrm{kDa}$ & $4.00 \pm 0.84$ & $8.77 \pm 0.42$ & $7.73 \pm 1.51$ & $1.63 \pm 0.17$ \\
\hline $\mathrm{CD} / \mathrm{CD}+\mathrm{CBM}$ & & 0.27 & 1.19 & 0.88 & 0.14 \\
\hline \multicolumn{6}{|l|}{ Endoglucanase } \\
\hline $\begin{array}{c}\text { Cel7B } \\
\beta \text {-glucosidase }\end{array}$ & $55 \mathrm{kDa}$ & $1.21 \pm 0.14$ & $1.02 \pm 0.05$ & $1.96 \pm 0.34$ & $2.09 \pm 0.37$ \\
\hline $\begin{array}{l}\text { Cel3A } \\
\text { Xylanase }\end{array}$ & $81 \mathrm{kDa}$ & $51.66 \pm 8.66$ & $56.71 \pm 2.08$ & $94.68 \pm 5.91$ & $19.24 \pm 5.03$ \\
\hline XYNIV & $55 \mathrm{kDa}$ & $2.10 \pm 0.26$ & $2.03 \pm 0.21$ & $1.50 \pm 0.17$ & $1.01 \pm 0.06$ \\
\hline \multicolumn{6}{|l|}{ Mannanase } \\
\hline Man5A & $53 \mathrm{kDa}$ & $1.74 \pm 0.71$ & $1.21 \pm 0.80$ & $1.83 \pm 0.36$ & $2.50 \pm 0.57$ \\
\hline Sum $^{3}$ & & 9.09 & 6.67 & 7.61 & 7.12 \\
\hline
\end{tabular}

${ }^{1} \mathrm{CD}$, catalytic domain. ${ }^{2} \mathrm{CBM}$, carbohydrate binding module. ${ }^{3}$ The sum was calculated with the ratio of the enzyme amount to the total amount of cellulase of T. reesei. The enzyme amount ratios are presented such as CD + CBM (50.54\%), CD (22.46\%), Cel7B (7.5\%), Cel3A (1.38\%), XYNIV (0.1\%), and Man5A (0.25\%), based on Herpoel-Gimbert et al. 2008 [36]. This corresponds to $82.13 \%$ of the secretome protein of T. reesei.

The proteins of the cellulase cocktail of T. reesei were adsorbed by $25.3 \%, 19.6 \%, 17.1 \%$, and $21.8 \%$ of the total secreted proteins by $10 \mathrm{mg} \mathrm{mL}^{-1}$ lignin of oak, pine, rice straw, and kenaf, respectively. The major enzymes (CBHs, Cel7B, Cel3A, XYNIV, and Man5A) were adsorbed by $9.09 \%, 6.67 \%, 7.61 \%$, and $7.12 \%$ (Table 2). The others, which contain small amounts of enzymes such as non-quantified $\beta$-glucosidases, endoglucosidases, $x y-$ lanases, $\beta$-xylosidases, and accessory enzymes (polysaccharide monooxygenases, esterases, arabinofuranosidase, swollenins, etc.) were more adsorbed, by $16.2 \%, 12.9 \%, 9.5 \%$, and $14.7 \%$ by the lignin of oak, pine, rice straw, and kenaf, respectively, which is inferred to be responsible for the enzymatic retardation at the early stages of saccharification.

\section{Conclusions}

Adsorption of enzymes onto lignin during processing of lignocellulosic biomass leads to severe problems and increases the cost of the bioconversion process. Major cellulolytic and xylanolytic enzymes are CBHs, Cel7B, Cel3A, XYNIV, and Man5A. Here, we quantified the adsorption of these enzymes onto lignin under various practical enzymatic hydrolysis conditions. Total adsorption ratios of the major enzymes onto different lignin types from oak, pine, rice straw, and kenaf were found to be $9.09 \%, 6.67 \%, 7.61 \%$, and $7.12 \%$, respectively, with respect to the $82.13 \%$ secretome of $T$. reesei. Adsorption of hydrolytic enzymes onto lignin, especially that of helping enzymes such as $\beta$-glucosidase, xylanase, and mannanase, is inferred to render enzymatic hydrolysis inefficient in the early stage. In addition, the adsorption on low-expressed secretome enzymes in the cellulase cocktail, of $9.5-16.2 \%$, is predicted to impede the acceleration of the enzymatic hydrolysis rate. The enzymatic and physical interference of lignin hinders the economic potential of the pretreatment and saccharification process. For this purpose, delignification of lignocellulosic biomass via pretreatment can help achieve economic saccharification processes. 
Author Contributions: D.-S.L. performed experiments and analysis of data with Y.S. and drafted the manuscript. Y.-G.L. and Y.S. prepared popping pretreated-woody and -herbaceous lignocellulosic biomasses. H.-J.B. designed the project, critically analyzed the data, and improved the manuscript. All authors have read and agreed to the published version of the manuscript.

Funding: This research was supported by the National Research Foundation of Korea (NRF) grant funded by the Korea government (MSIP) (NRF-2020R1I1A1A01067895).

Institutional Review Board Statement: Not applicable.

Informed Consent Statement: Not applicable.

Data Availability Statement: The data presented in this study are available on request from the corresponding author.

Conflicts of Interest: The authors declare no conflict of interest.

\section{References}

1. Anwar, Z.; Gulfraz, M.; Irshad, M. Agro-industrial lignocellulosic biomass a key to unlock the future bio-energy: A brief review. J. Radiation Res. App. Sci. 2014, 168-173. [CrossRef]

2. Kahar, P. Synergistic effects of pretreatment process on enzymatic digestion of rice straw for efficient ethanol fermentation. Environ. Biotechnol. New Approaches Prospect. Appl. 2013, 73-77. [CrossRef]

3. Himmel, H.E.; Ding, S.Y.; Johnson, D.K.; Adney, W.S.; Nimlos, M.R.; Brady, J.W.; Foust, T.D. Biomass recalcitrance: Engineering plants and enzymes for biofuels production. Science 2007, 315, 804-807. [CrossRef] [PubMed]

4. Lee, D.S.; Lee, Y.G.; Song, Y.; Cho, E.J.; Bae, H.J. Hydrolysis patterns of xylem tissues of hardwood pretreated with acetic acid and hydrogen peroxide. Front. Energy Res. 2020, 8, 34. [CrossRef]

5. Liu, H.; Sun, J.; Leu, S.Y.; Chen, S.C. Toward a fundamental understanding of cellulase-lignin interactions in the whole slurry enzymatic saccharification process. Biofuels Bioprod. Bioref. 2016, 10, 648-663. [CrossRef]

6. Valjamae, P.; Sild, V.; Pettersson, G.; Johansson, G. The initial kinetics of hydrolysis by cellobiohydrolases I and II is consistent with a cellulose surface- erosion model. Eur. J. Biochem. 1998, 253, 469-475. [CrossRef]

7. Igarashi, K.; Uchihashi, T.; Koivula, A.; Mad, M.; Kumura, S.; Okamoto, T.; Penttila, M.; Ando, T.; Samejima, M. Traffic jams reduce hydrolytic efficiency of cellulase on cellulose surface. Science 2011, 333, 1279-1282. [CrossRef]

8. Vermaas, J.V.; Petridis, L.; Qi, X.; Schulz, R.; Lindner, B.; Smith, J.C. Mechanism of lignin inhibition of enzymatic biomass deconstruction. Biotechnol. Biofuels 2015, 8, 1-16. [CrossRef]

9. Sammond, D.W.; Yarbrough, J.M.; Mansfield, E.; Bomble, Y.J.; Hobdey, S.E.; Decker, S.R.; Taylor, L.E.; Resch, M.G.; Bozell, J.J.; Himmel, M.E.; et al. Predicting enzyme adsorption to lignin films by calculating enzyme surface hydrophobicity. J. Biol. Chem. 2014, 289, 20960-20969. [CrossRef]

10. Kumar, R.; Wyman, C.E. Access of cellulase to cellulose and lignin for poplar solids produced by leading pretreatment technologies. Biotechnol. Prog. 2009, 25, 807-819. [CrossRef]

11. Yoo, C.G.; Meng, X.; Pu, Y.; Ragauskas, A.J. The critical role of lignin in lignocellulosic biomass conversion and recent pretreatment strategies: A comprehensive review. Bioresour. Technol. 2020, 301, 122784. [CrossRef] [PubMed]

12. Yang, Q.; Pan, X. Correlation between lignin physicochemical properties and inhibition to enzymatic hydrolysis of cellulose. Biotechnol. Bioeng. 2016, 113, 1213-1224. [CrossRef] [PubMed]

13. Berlin, A.; Balakshin, M.; Gilkes, N.; Kadla, J.; Maximenko, V.; Kubo, S.; Saddler, J. Inhibition of cellulase, xylanase and $\beta$-glucosidase activities by softwood lignin preparations. J. Biotechnol. 2006, 125, 198-209. [CrossRef]

14. Lu, X.; Zheng, X.; Li, X.; Zhao, J. Adsorption and mechanism of cellulase enzymes onto lignin isolated from corn stover pretreated with liquid hot water. Biotechnol. Biofuels 2016, 9, 118. [CrossRef] [PubMed]

15. Pareek, N.; Gillgren, T.; Jonsson, L.J. Adsorption of proteins involved in hydrolysis of lignocellulose on lignins and hemicelluloses. Bioresour. Technol. 2013, 148, 70-77. [CrossRef] [PubMed]

16. Gao, D.; Chundawat, S.P.S.; Uppugundla, N.; Balan, V.; Dale, B.E. Binding characteristics of Trichoderma reesei cellulases on untreated, ammonia fiber expansion (AFEX), and dilute-acid pretreated lignocellulosic biomass. Biotechnol. Bioeng. 2011, 108, 1788-1800. [CrossRef] [PubMed]

17. Ying, W.; Shi, Z.; Yang, H.; Xu, G.; Zheng, Z.; Yang, J. Effect of alkaline lignin modification on cellulase-lignin interactions and enzymatic saccharification yield. Biotechnol. Biofuels 2018, 11, 1-13. [CrossRef]

18. Guo, F.; Shi, W.; Sun, W.; Li, X.; Wang, F.; Zhao, J.; Qu, Y. Differences in the adsorption of enzymes onto lignins from diverse types of lignocellulosic biomass and the underlying mechanism. Biotechnol. Biofuels 2014, 7, 1-10. [CrossRef] [PubMed]

19. Wi, S.G.; Chung, B.Y.; Lee, Y.G.; Yang, D.J.; Bae, H.J. Enhanced enzymatic hydrolysis of rapeseed straw by popping pretreatment for bioethanol production. Bioresour. Technol. 2011, 5788-5793. [CrossRef]

20. Wi, S.G.; Choi, I.S.; Kim, K.H.; Kim, H.M.; Bae, H.J. Bioethanol production from rice straw by popping pretreatment. Biotechnol. Biofules 2013, 6, 1-7. [CrossRef] 
21. Luhtala, N.; Parker, R. LSM1 over-expression in Saccharomyces cerevisiae depletes U6 snRNA levels. Nucleic Acids Res. 2009, 37, 5529-5536. [CrossRef] [PubMed]

22. Vanholme, R.; Demedts, B.; Morreel, K.; Ralph, J.; Boerjan, W. Lignin biosynthesis and structure. Plant. Biol. 2010, 153, 895-905. [CrossRef]

23. Mansfiled, S.D.; Kim, H.; Lu, F.; Ralph, J. Whole plant cell wall characterization using solution-state 2D NMR. Nat. Protoc. 2012, 7, 1579-1589. [CrossRef] [PubMed]

24. Sewalt, V.J.H.; Glasser, W.G.; Beauchemin, K.A. Lignin impact on fiber degradation. 3. Reversal of inhibition of enzymatic hydrolysis by chemical modification of lignin and by addictives. J. Agric. Food. Chem. 1997, 45, 1823-1828. [CrossRef]

25. Li, X.; Zheng, Y. Lignin-enzyme interaction: Mechanism, mitigation approach, modeling, and research prospects. Biotechnol. Adv. 2017, 35, 466-489. [CrossRef] [PubMed]

26. Hage, R.E.; Brosse, N.; Chrusciel, L.; Sanchez, C.; Sannigrahi, P.; Ragauskas, A. Characterization of milled wood lignin and ethanol organosolv lignin from miscanthus. Polym. Degrad. Stab. 2009, 94, 1632-1638. [CrossRef]

27. Tayyab, M.; Noman, A.; Islam, W.; Waheed, S.; Arafat, Y.; Ali, F.; Zaynab, M.; Lin, S.; Zhang, H.; Lin, W. Bioethanol production from lignocellulosic biomass by environment-friendly pretreatment methods: A review. Appl. Ecol. Environ. Res. 2018, 16, 225-249. [CrossRef]

28. Liu, X.; Bouxin, F.; Fan, J.; Budarin, V.L.; Hu, C.; Clark, J.H. Recent advances in the catalytic depolymerization of lignin towards phenolic chemicals: A review. ChemSusChem. 2020, 13, 4296-4317. [CrossRef]

29. Rosado, M.J.; Rencoret, J.; Marques, G.; Gutierrez, A.; Rio, J.C. Structural characteristics of the guaiacyl-rich lignins from rice (Oryza sativa L.) husks and straw. Front. Plant Sci. 2021, 12, 195. [CrossRef] [PubMed]

30. Kuroda, K.; Izumi, A.; Mazumder, B.B.; Ohtani, Y.; Sameshima, K. Characterization of kenaf (Hibiscus cannabinus) lignin by pyrolysis-gas chromatography-mass spectrometry in the presence of tetramethylammonium hydroxide. J. Anal. Appl. Pyrolysis 2002, 64, 453-463. [CrossRef]

31. Yarbrough, J.M.; Mittal, A.; Mansfield, E.; Taylor, L.E.; Hobdey, S.E.; Sammond, D.W.; Blomble, Y.J.; Crowley, M.F.; Decker, S.R.; Himmel, M.E.; et al. New perspective on glycoside hydrolase binding to lignin from pretreated corn stover. Biotechnol. Biofuels 2015, 8, 1-14. [CrossRef]

32. Adav, S.; Ravindran, L.T.; Chao, L.; Tan, S.; Singh, S.K. Proteomic analysis of $\mathrm{pH}$ and strains dependent protein secretion of Trichoderma reesei. J. Proteome Res. 2011, 10, 4579-4596. [CrossRef] [PubMed]

33. Lourenco, A.; Pereira, H. Chapter 3: Compositional variability of lignin in biomass. In Lignin-Trends and Applications; IntechOpen: London, UK, 2017; pp. 65-98.

34. Mouthier, T.; Aledoorm, M.M.; Pel, H.; Schols, H.A.; Gruppen, H.; Kabel, M.A. Corn stover lignin is modified differently by acetic acid compared to sulfuric acid. Industrial Crops Products 2018, 121, 160-168. [CrossRef]

35. Biely, P.; Puchart, V.; Stringer, M.A.; Morkeberg Krogh, K.B.R. Trichoderma reesei XYN VI- a novel appendage-dependent eukaryotic glucuronoxylan hydrolase. FEBS J. 2014, 281, 3894-3903. [CrossRef] [PubMed]

36. Herpoel-Gimbert, I.; Margeot, A.; Dolla, A.; Jan, G.; Molle, D.; Lignon, S.; Mathis, H.; Sigoillot, J.C.; Monot, F.; Asther, M. Comparative secretome analyses of two Trichoderma reesei RUT-30 and CL847 hypersecretory strains. Biotechnol. Biofuels 2008, 18.

37. Ramoni, J.; Darchetti-Deschman, M.; Seidl-Seiboth, V. Trichoderma reesei xylanase 5 is defective in the reference strain QM6a but functional alleles are present in other wild-type strains. App. Microbiol. Biotechnol. 2017, 101, 4139-4149. [CrossRef]

38. Palonene, H.; Tjerneld, F.; Zacchi, G.; Tenkanen, M. Adsorption of Trichoderma reesei CBH1 and EG II and their catalytic domains on steam pretreated softwood and isolated lignin. J. Biotechnol. 2004, 107, 65-72. [CrossRef]

39. Rahikainen, J.L.; Martin-Sampeder, R.; Hikkinen, H.; Rovo, S.; Marjamaa, K.; Tamminen, T.; Rojas, O.J.; Kruus, K. Inhibitory effect of lignin during cellulose bioconversion: The effect of lignin chemistry on non-productive enzyme adsorption. Bioresour. Technol. 2013, 133, 270-278. [CrossRef] [PubMed]

40. Tokunaga, Y.; Nagata, T.; Suetomi, T.; Oshiro, S.; Kondo, K.; Katahira, M.; Watanabe, T. NMR analysis on molecular interaction of lignin with amino acid residues of carbohydrate-binding module from Trichoderma reesei Cel7A. Sci. Rep. 2019, 9, 1-12. [CrossRef] [PubMed]

41. Ko, J.K.; Ximenes, E.; Kim, Y.; Laisch, M.R. Adsorption of enzyme onto lignin of liquid hot water pretreated hardwoods. Biotechnol. Bioeng. 2015, 112, 447-456. [CrossRef] [PubMed]

42. Kumar, R.; Singh, S.; Singh, O.V. Bioconversion of lignocellulosic biomass: Biochemical and molecular perspectives. J. Ind. Microbiol. Biotechnol. 2008, 35, 377-391. [CrossRef] [PubMed]

43. Carli, S.; Carneiro, L.A.B.D.C.; Ward, R.J.; Meleiro, L.P. Immobilization of a $\beta$-glucosidase and an endoglucanase in ferromagnetic nanoparticles: A study of synergistic effects. Protein Expr. Purif. 2019, 160, 28-35. [CrossRef]

44. Guo, B.; Sato, N.; Biely, P.; Amano, Y.; Nozaki, K. Comparison of catalytic properties of multiple $\beta$-glucosidases of Trichoderma reesei. Appl. Microbiol. Biotechnol. 2016, 100, 4959-4968. [CrossRef] [PubMed]

45. Lee, H.L.; Chang, C.K.; Jeng, W.Y.; Wang, A.H.J.; Kiang, P.H. Mutations in the substrate entrance region of $\beta$-glucosidase from Trichoderma reesei improve enzyme activity and thermostability. Protein Eng. Des. Sel. 2012, 25, 733-740. [CrossRef] [PubMed]

46. Murphy, L.; Bohlin, C.; Baumann, M.J.; Olsen, S.N.; Sorensen, T.H.; Anderson, L.; Borch, K.; Westh, P. Product inhibition of five Hypocrea jecorina cellulases. Enzyme Microb. Technol. 2013, 52, 163-169. [CrossRef] [PubMed]

47. Yeo, S.L.; Shazilah, K.; Suhaila, S.; Abu, B.F.D.; Murad, A.M.A. In-silico analysis of Aspergillus niger beta-glucosidases. AIP Conf. Proc. 2014, 1614, 537-5543. [CrossRef] 
48. Souza, W.R.D.; Gouvea, P.F.D.; Saboldi, M.S.; Malavazi, I.; Bernardes, L.A.D.S.; Goldman, M.H.S.; Vries, R.P.D.; Oliveiar, J.V.D.C.; Goldman, G.H. Transcriptome analysis of Aspergillus niger grown on sugarcane bagasse. Biotechnol. Biofuels. 2011, 4, 1-17. [CrossRef]

49. Seidle, H.F.; Marten, I.; Shoseyov, O.; Huber, R.E. Physical and kinetic properties of the family $3 \beta$-glucosidase from Aspergillus niger which is important for cellulose breakdown. Protein. J. 2004, 23, 11-23. [CrossRef]

50. Junior, A.B.; Borges, D.G.; Tardioli, P.W.; Farinas, C.S. Characterization of glucosidase produced by Aspergillus niger under solid-state fermentation and partially purified using MANAE-Agarose. Biotechnol. Res. Inter. 2014. [CrossRef]

51. Zhao, J.; Shi, D.; Yang, S.; Lin, H.; Chen, H. Identification of an intracellular $\beta$-glucosidase in Aspergillus niger with transglycosylation activity. App. Microbiol. Biotechnol. 2020, 104, 8367-8380. [CrossRef]

52. Maki-Arvela, P.; Salmi, T.; Holmbom, B.; Willfor, S.; Murzin, D.Y. Synthesis of sugars by hydrolysis of hemicelluloses-A review. Chem. Rev. 2011, 111, 5638-5666. [CrossRef]

53. Quyang, J.; Yan, M.; Kong, D.; Xu, L. A complete protein pattern of cellulase and hemicellulose genes in the filamentous fungus Trichoderma reesei. Biotechnol. J. 2006, 1, 1266-1274.

54. Qing, Q.; Yang, B.; Wyman, C.E. Xylooligomers are strong inhibitors of cellobiose hydrolysis by enzymes. Bioresour. Technol. 2010, 101, 9624-9630. [CrossRef]

55. Shivastava, S.; Shukla, P.; Mukhopadhyay, K. Purification and preliminary characterization of a xylanase from Thermomyces lanuginosus strain SS-8. 3 Biotech. 2011, 1, 255-259. [CrossRef]

56. Winger, A.M.; Heazlewood, J.L.; Chan, L.J.G.; Petzold, C.J.; Permaul, K.; Singh, S. Secretome analysis of the thermophilic xylanase hyper-producer Thermomyces lanuginosus SSBP cultivated on corn cobs. J. Ind. Microbiol. Biotechnol. 2014, 41, 1687-1696. [CrossRef] [PubMed]

57. Duan, C.J.; Feng, Y.L.; Cao, Q.L.; Huang, M.Y.; Feng, J.X. Identification of a novel family of carbohydrate-binding modules with broad ligand specificity. Sci. Rep. 2016, 6, 1-8. [CrossRef]

58. Chauhan, P.S.; Puri, N.; Sharma, P.L.; Gupta, N. Mannanases: Microbial sources, production, properties and potential biotechnological applications. Appl. Microbiol. Biotehcnol. 2012, 93, 1817-1830. [CrossRef] [PubMed]

59. Clarke, J.H.; Davidson, K.; Rixon, J.E.; Halstead, J.R.; Fransen, M.P.; Gilbert, H.J.; Hazlewood, G.P. A comparison of enzyme-aided bleaching of softwood paper pulp using combinations of xylanase, mannanase and $\alpha$-galactosidase. Appl. Microbiol. Biotechnol. 2000, 53, 661-667. [CrossRef] [PubMed]

60. von Freiesleben, P.; Spodsberg, N.; Stenbak, A.; Stalbrand, H.; Krogh, K.B.R.M.; Meyer, A.S. Boosting of enzymatic softwood saccharification by fungal GH5 and GH26 endomannanases. Biotechnol. Biofuels. 2018, 11, 194. [CrossRef]

61. Varnai, A.; Huikko, L.; Pere, J.; Siika-aho, M.; Viikari, L. Synergistic action of xylanase and mannanase improves the total hydrolysis of softwood. Bioresour. Technol. 2011, 102, 9096-9104. [CrossRef]

62. Hagglund, P.; Eriksson, T.; Collen, A.; Nerinckx, W.; Claeyssens, M.; Stalbrand, H. A cellulose-binding module of the Trichoderma reesei $\beta$-mannanase Man5A increases the mannan-hydrolysis of complex substrates. J. Biotechnol. 2003, 101, 37-48. [CrossRef] 